\title{
Primary Cultures Derived From Bovine Papillomavirus-Infected Lesions As Model To Study Metabolic Deregulation
}

Rodrigo Pinheiro Araldi ${ }^{1,2,}$ Paulo Luiz de Sá Júnior ${ }^{1,}$ Roberta Fiusa Magnellii ${ }^{1,2,}$ Diego Grando Módolo ${ }^{1,}$ Jacqueline Mazzuchelli de Souza ${ }^{1,}$ Diva Denelle Spadacci-Morena ${ }^{3}$, Rodrigo Franco de Carvalho ${ }^{1,}$ Willy Beçak $^{1,}$ Rita de Cassia Stocco, ${ }^{1, *}$

${ }^{1}$ Genetics Laboratory, Butantan Institute, Vital Brazil Avenue 1500, São Paulo-SP, Brazil

${ }^{2}$ Biotechnology Interunit Post-graduation Program IPT/Butantã/USP, University of São Paulo, Lineu Prestes 2415, São Paulo-SP, Brazil

${ }^{3}$ Physiopathology Laboratory, Butantan Institute, Vital Brazil 1500, São Paulo-SP, Brazil

${ }^{\star}$ Corresponding author: Rita de Cassia Stocco, Genetics Laboratory (Viral Oncogenesis), Butantan Institute, Vital Brazil St. 1500, São Paulo-SP, Brazil, Phone/Fax: 55 (11) 2627-9701; E-mail: rita.stocco@butantan.gov.br

Received Date: November 10, 2016; Accepted Date: November 23, 2016; Published Date: November 25, 2016

Citation: Rodrigo Pinheiro Araldi, et al. (2016) Primary Cultures Derived From Bovine Papillomavirus-Infected Lesions As Model To Study Metabolic Deregulation. J Cancer Res Therap Oncol 4: 1-18

\begin{abstract}
Bovine papillomavirus (BPV) is the etiological agent of bovine papillomatosis, disease characterized by the presence of multiple papillomas that can regress or to progress to malignances. Due to the pathological similarities with the human papillomavirus (HPV), BPV is considered a prototype to study the papillomavirus-associated oncogenic process. Although it is clear that both BPV and HPV can interact with host chromatin, the interaction of these viruses with cell metabolism remains understudied due to the little attention given to primary cultures derived from papillomavirus-infected lesions. Thus, this study analyzed the energy metabolism, including the mitochondrial membrane potential $(\Delta \Psi \mathrm{m})$ and Reactive Oxygen Species (ROS) of cells derived from cutaneous papilloma, fibropapilloma and Esophageal Carcinoma (EC) as model to evaluate the cell metabolism. These cells were cultivated until sixth passage and subjected to BPV DNA sequences identification by PCR using specific primers to BPV-1, 2 and 4. PCR results showed the presence and maintenance of at least one BPV type along the six passages analyzed. Cells derived from normal skin, without BPV DNA sequences were used as control. Results of energy metabolism showed the loss of $\Delta \Psi \mathrm{m}$ in fibropapilloma and EC cells, suggesting a metabolic switch compatible to the activation of aerobic glycolysis. Cutaneous papilloma and normal skin cells showed the maintenance of $\Delta \Psi \mathrm{m}$. Paradoxically, cutaneous papilloma and fibropapilloma presented high levels of ROS production, while the EC cells reduced the ROS levels, reinforcing the activation of glycolytic metabolism. Our results suggest that the metabolic switch is mediated by BPV E6 oncoprotein, since the addition of this oncoprotein in normal cells promoted the oxidative stress. The oxidative stress showed able to activate the STAT3 nuclear factor in papilloma and fibropapilloma cells, contributing to metabolic deregulation. These data suggest that primary cultures are useful model to study the interaction between BPV and cell metabolism.
\end{abstract}

Keywords: BPV; Mitochondrial membrane potential; Reactive oxygen species; Fibropapilloma; Esophageal carcinoma

Abreviations: BPV: bovine papillomavirus, HPV: human papillomavirus, SOD: superoxide dismutase, GpX: glutathione peroxidase, $\triangle \Psi \mathrm{m}$ : mitochondrial membrane potential, ROS: reactive oxygen species, OXPHOS: oxidative phosphorylation, DCFH-DA: Dichloro-dihydro-fluorescein diacetate; HCV: hepatitis C virus, EBV: Epstein-Barr virus, DENV: dengue virus 


\section{Introduction}

Although recognized as a multifactorial disease, it is estimated that $23 \%$ of all human cancers are associated to infectious agents [1-3]. Among these, the human papillomavirus (HPV) is responsible to about $30 \%$ of all incident infectious agentassociated cancer cases $[1,2]$. These data demonstrate that viral oncogenesis studies are mandatory in attempt to reduce the mortality rate by HPV-associated cancer [4]. In this scene, the bovine papillomavirus (BPV) emerges as an useful model to study the papillomavirus-associated oncogenic process, since both HPV and BPV share morphological, pathological and pathogenic characteristics [5-7]. For these reasons, BPV is considered a prototype to study the molecular biology and cell transformation mechanism of HPV [8]. Moreover, both viruses are associated to benign (warts) and malignant neoplasm. Although it is well stated that both HPV [9] and BPV promote DNA damages (mutations) that can lead to cancer initiation [10-13], there are few studies about the viral action in cell metabolism [5,14-16]. This occurs due to the lack of attention given to in vitro models [17]. In this sense, since 2003, our group has demonstrated that primary cultures derived from BPV-infected lesions are useful model to understand the viral interaction with host chromatin [18]. This because, primary cells derived from BPV-infected cutaneous papilloma, esophageal papilloma and urinary bladder lesions present chromosome aberrations [19] similar to those verified in BPV-infected lymphocytes $[10,12,20,21]$. Similar results were also described in cell cultures derived from bovines, canines and equines infected with papillomavirus [22]. Currently, Potocki et al. [14] reported that sarcoid-derived fibroblast present a loss of mitochondrial membrane potential and changes in energy-supplying pathways in BPV-1-positive cells, which are typical verified in cancer cells. In other study, based on HPV-16, Williams et al. [15] demonstrated that $\mathrm{E}^{*}$ oncoprotein, a splicing variant of E6 oncoprotein, promotes the SOD2 and GPx antioxidant enzymes downregulation, resulting in oxidative stress in $\mathrm{CaS}$ $\mathrm{ki}$ and $\mathrm{SiHa}$ cells (derived from human cervical carcinoma). These results suggest that in vitro models are useful models to study the virus-associated metabolic deregulation. However, up to date, there is not any study about the cell metabolism of cutaneous papilloma, fibropapilloma and esophageal carcinoma infected by BPV.

Since to 1953 it is known that energy metabolism deregulation is a cancer hallmark [23-26]. In normal (quiescent) cells, glucose is metabolized to pyruvate in the cytosol by a multi-step process kwon as glycosysis [27]. The pyruvate is predominately directs to mitochondrial matrix where is oxidized to acetyl Coenzyme A (Co-A), that fed the tricarboxylic acid cycle, followed by oxidative phosphorylation (OXPHOS) $[5,27,28]$. This process generates an electron gradient with results in mitochondrial membrane potential $(\Delta \Psi \mathrm{m})[5,28]$. This gradient is required to ATP synthesis [29], however, leads to reactive oxygen species (ROS) production, which can interact with proteins, lipids and DNA, resulting in nucleotide oxidation and/or DNA breaks (clastogenesis) [5].
By the contrast, most cancer cells increase the glucose uptake and glycolytic rates even in aerobic conditions, converting the pyruvate to lactate $[5,27,30,31]$. This metabolic switch, known as "Warburg effect", guarantees the ATP supply to cell proliferation, reducing the ROS levels, which can lead to apoptosis, conferring a protective action to cancer cells [5]. Currently studies suggest that the STAT3 nuclear transcription factor is the pivot of metabolic switch verified in transformed cells $[32,33]$. This because, the STAT3 factor promotes the glucose6-phosphatase and fructose-6-phosphatase downregulation, reducing the activity of respiratory chain complex I and, therefore, the OXPHOS [34]. Based on these data, we analyzed the cell metabolism of cells derived from cutaneous papilloma, fibropapilloma and esophageal carcinoma infected by BPV. We also evaluated the action of BPV-1 E6 oncoprotein on cell metabolism of BPV-free cells. Our results showed that primary cultures derived from BPV-infected lesions are useful model to study the metabolic deregulation verified during the pathologic evolution of neoplasm (benign to malignant).

\section{Material and Methods Cell culture}

To elucidate the ROS-dependent signaling pathways is a laborious task, because free oxygen (singlet) has a short life time, being quickly converted to other reactive species, able to link to other molecules. In this sense, the cell cultures emerges as useful models to study the oxidative stress $[5,35]$. Thus, this study employed five primary culture: one of BPV-free normal skin (control), one of cutaneous papilloma (papilloma 01), two of fibropapillomas (papilloma 02 and 03) and one of esophageal carcinoma. These primary cultures were obtained by Campos et al. [19] from tissue fragments collected from adult bovines (Bos taurus), being part of biological collection of Genetics Laboratory of Butantan Institute. This study was approved by the Ethics Committee of Butantan Institute under process $1319 / 14$. The cells were seeded in culture flasks of 25 $\mathrm{cm} 2$, containing $5 \mathrm{~mL}$ of DMEM medium (Cultilab, Campinas, Brazil), supplemented with 15\% fetal bovine serum (Cultilab, Campinas, Brazil) and 1\% ampicillin-streptomycin (Cultilab, Campinas, Brazil). The material was incubated at $37^{\circ} \mathrm{C}, 5 \%$ CO2 up to $80 \%$ confluence (about 72 hours). The monolayer was disaggregated with $0.01 \%$ EDTA solution to preserve the cell morphology. Primary cultures were cultivated until sixth passage (P1-P6).

\section{BPV DNA sequence identification}

One culture flask of each of primary culture was subjected to DNA extraction using the QIAamp DNA Blood Mini Kit (Qiagen, Germany), according to manufacturer's instructions. DNA was quantified in BioPhomometer Plus spectrophotometer (Eppendorf, Germany) and subjected to BPV DNA sequence identification by PCR. The PCR was performed in a reaction volume of $25 \mu \mathrm{L}$, composed of $10.0 \mu \mathrm{L}$ of Dream Taq Green (Thermo Scientific, USA), 8.0 $\mu \mathrm{L}$ of DNase-free water, $1.0 \mu \mathrm{L}$ of forward primer, $1.0 \mu \mathrm{L}$ of reverse primer, and $5.0 \mu \mathrm{L}$ of DNA template (200 ng). 
For BPV sequence identification, we used specific primers for BPV-1 and 2 because these are the most frequent types of virus identified worldwide [36]. We also investigated the presence of BPV-4 due to association to esophageal carcinoma [37]. Moreover, these primers have most sensitivity than degenerate primers (FAP59/64 and MY09/11) [36], which could result in false-negative results. The BPV-1 primer pair (forward 5'GAGCGCCTGCTAACTATAGGA-3' and reverse 5'- ATCTGTTGTTTGGGTGGTGAC-3') amplify the L1 region, resulting in an amplicon of $301 \mathrm{bp}$, the BPV-2 primer pair (forward 5'-GTTATACCACCCAAAGAAGACCCT-3' and reverse 5'-TGGTTGCAACAGCTCTCTTTCTC-3') amplify the L2 region, resulting in $164 \mathrm{bp}$ amplicon and BPV-4 primer pair (forward 5'- GCTGACCTTCCAGTCTTAAT-3' and reverse 5'- CAGTTTCAATCTCCTCTTCA-3') amplify the E7 region, resulting in $170 \mathrm{bp}$ amplicon. PCR was performed in PTC-100 Programmable Thermal Controller (MJ Research, USA), using the following program: 3 minutes at $94^{\circ} \mathrm{C}$ (initial denaturation), 35 cycles of 50 seconds at $94^{\circ} \mathrm{C}$ (denaturation), 1 minute at $60^{\circ} \mathrm{C}$ (annealing), 1 minute at $72^{\circ} \mathrm{C}$ (extension), and a final extension of 5 minutes at $72^{\circ} \mathrm{C}$. Genomes of BPV-1 (GenBank access number AB626705), 2 (M20219.1), and 4 (X0581.1) cloned in pAT153 vector [38], using Escherichia coli were used as positive control. These genomes are part of a biological collection at the Genetics Laboratory of Butantan Institute. PCR products were analyzed in $2.0 \%$ agarose gel in TAE buffer $(0.04$ $\mathrm{M}$ Tris base, $1 \mathrm{M}$ acetic acid, $50 \mathrm{mM}$ EDTA, $\mathrm{pH}$ 8.0) stained with $1.0 \%$ GelRed (Biotium, Hayward, USA). Electrophoresis was performed at $100 \mathrm{~V}, 300 \mathrm{~mA}$ for two hours. The $100 \mathrm{bp}$ DNA Ladder (Invitrogen, Carlsbad, USA) was employed as marker.

\section{Cell Cycle analysis}

Cell cycle analysis was performed by flow cytometry, according to De-Sá-Júnior et al. [35], method widely used to evaluate cell proliferation [39-42]. The cells in second passage (P2) were synchronized by serum deprivation for 24 hours and induced to reenter the cell cycle by the subsequent reintroducing $10 \%$ of serum to culture medium. Cells were collected and fixed with cold $70 \%$ ethanol and stored at $-20^{\circ} \mathrm{C}$. Afterwards, the cells were washed, re-suspended in PBS and incubated at $37^{\circ} \mathrm{C}$ for 45 minutes with $10 \mathrm{mg} / \mathrm{mL}$ RNase and $1 \mathrm{mg} / \mathrm{mL}$ propidium iodide (PI) (Invitrogen, Carlsbad, USA). Flow cytometric analysis was performed in FACSCalibur flow cytometer (Becton Dickinson, San Jose, CA). A total of 20,000 events were analyzed. The percentage of DNA content in the different cell cycle phases was determined using Modfit LT software (Verity Software House, Topsham, ME).

\section{Mitochondrial membrane potential $(\Delta \Psi \mathrm{m})$ anal- ysis}

The mitochondrial membrane potential $(\Delta \Psi \mathrm{m})$ was evaluated by using the MitoTracker probe (Invitrogen, Carlsbad, USA), according to De-Sá-Júnior et al. [35]. MitoTracker is probe derived from $\mathrm{X}$-rosamine, which has selective permeability to mitochondrial membrane.
One flask of each cell line, in second passage (P2), was destined to $\Delta \Psi \mathrm{m}$ analysis. The second passage was used to avoid false positive results due to cell manipulation. Cells were incubated with $20 \mathrm{nM}$ of MitoTracker probe, diluted in dimethyl sulfoxide (DMSO) at $37^{\circ} \mathrm{C}$. Cells were washed with PBS and subjected to monolayer disaggregation. A total of 10,000 events were analyzed in Accuri C6 flow cytometer (BD Bioscience, USA). In addition, it was evaluated the action of BPV-1 E6 recombinant oncoprotein in $\triangle \Psi \mathrm{m}$. For this study, BPV-free cell line (normal skin) was treated with $1 \mu \mathrm{g} / \mathrm{mL}$ of BPV-1 recombinant oncoprotein for 24 hours and after, subjected to the MitoTracker protocol. All analysis of $\Delta \Psi \mathrm{m}$ was performed in duplicate. The E6 recombinant oncoprotein was expressed and purified according Mazzuchelli-de-Souza et al. [43]. The identity of this protein was previously verified in Araldi et al. [44]. The E6 oncoprotein concentration was chosen according to the literature, since the administration of $1 \mu \mathrm{g} / \mathrm{mL}$ of E6 oncoprotein has been suggest as therapeutic vaccine against both BPV and HPV [45]. Statistical analysis was based on cell percentage and mean of fluorescence intensity (MFI) and stand deviation, since the mean of fluorescence is the most indicated method to analyze the expression of one specific marker in absolute terms. The Bonferroni's test, with significant level of 5\%, was used to multiple comparisons. The test was performed using the GraphPad Prim 5.0 software.

\section{Reactive oxygen species (ROS) detection assay}

The reactive oxygen species (ROS) generation was determined using the kit dichlorofluorescein diacetate (DCFH-DA) (Sigma, Germany), according to De-Sá-Júnior et al. [35]. Cells in second passage were incubated with $100 \mathrm{mM}$ of DCFHDA in a 6-well plate at a density of $4 \times 105$ cells per well at $5 \% \mathrm{CO} 2 / 95 \%$ air at $37^{\circ} \mathrm{C}$ for 30 minutes. After removing the DCFH-DA, the cells were washed twice with PBS. The cells were collected and analyzed in a flow cytometer (Accuri C6 flow cytometer, BD Bioscience, USA). Data were reported in terms of fold increase compared to a positive control (BPV uninfected cells treated with $100 \mathrm{nM}$ hydrogen peroxide). Using this same method, it was evaluated the action of BPV-1 E6 recombinant oncoprotein in ROS production. For this, normal skin cell line was treated with $1 \mu \mathrm{g} / \mathrm{mL}$ of E6 recombinant oncoprotein for 24 hours, produced according to Mazzuchellide-Souza et al. [43]. All analysis was performed in duplicate. Statistical analysis was based on cell percentage and mean of fluorescence intensity (MFI).

\section{Comet assay}

Comet assay was performed according to alkaline technique [45] in order to evaluate DNA breaks (clastogenesis) along of the six cell passages. An aliquot of $10 \mu \mathrm{L}(0.1 \times 105$ cells $)$ of the cells suspension was washed in PBS. Material was transferred to $0.2 \mathrm{~mL}$ polypropylene tubes and mixed with $75 \mu \mathrm{L}$ of low melting-point agarose $(0.7 \%$ in $\mathrm{PBS})$ at $37^{\circ} \mathrm{C}$. This LMA concentration do not affect the DNA migration (45). Cell suspension was transferred for $76 \times 26 \mathrm{~mm}$ microscope slides precoated with normal melting-point agarose (1.5\% in PBS) at $60^{\circ} \mathrm{C}$. After the agarose solidification $\left(4^{\circ} \mathrm{C}\right.$ for $\left.10 \mathrm{~min}\right)$, the coverslips were carefully removed, and the slides were immersed in lysis solution $(2.5 \mathrm{M} \mathrm{NaCl}, 100 \mathrm{mM} \mathrm{Na} 2 \mathrm{EDTA}, 10 \mathrm{mM}$ Tris$\mathrm{HCl}, \mathrm{pH} 10,1 \%$ Triton X100, 10\% DMSO) for 1 hour at $4^{\circ} \mathrm{C}$. 
Slides were placed into a horizontal electrophoresis apparatus containing the alkaline buffer ( $1 \mathrm{mM} \mathrm{Na} 2$ EDTA, $300 \mathrm{mM}$ $\mathrm{NaOH})$ at $4^{\circ} \mathrm{C}$. The slides were incubated for 40 minutes in this buffer to unwind the DNA. The electrophoresis was run for 20 minutes at fixed voltage of $25 \mathrm{~V}(0.83 \mathrm{~V} / \mathrm{cm})$ and $300 \mathrm{~mA}$. The slides were washed three times with neutralization buffer (0.4M Tris-HCl, pH 7.5) and fixed in 100\% ethanol for 5 minutes. All steps described above were carried out in the dark with to avoid DNA damage. The slides were stained with $20 \mu \mathrm{L}$ of propidium iodide $(4 \mu \mathrm{g} / \mathrm{mL})$ and visualized in Axio Scope A1 fluorescent microscopy (Carl Zeiss, Germany). A total of 100 nucleoids was analyzed per sample, which was classified in 0 (without damage), 1 (medium damage) and 2 (maximum damage). The number of nucleoids observed per class was multiplied to the class value, resulting in a comet score. Statistical analyses were performed by the Kruskal-Wallis test, followed by the Dunn test, both with $5 \%$ of significance level as proposed by Araldi et al. [45]. Linear regressions were used to evaluate the cell manipulation interference in clastogenesis.

\section{Analysis of STAT3 activation}

Given that the STAT3 transcription factor can bind to the P97 promoter, leading to E6 gene upregulation and reduces the activity of complex I and II of mitochondrial electron transporter chain, promoting the aerobic glycolysis activation [46], the levels of expression of this factor was analyzed by indirect immunofluorescence and flow cytometry.

Indirect immunofluorescence: a total of 1 X 105 cells were seeded per well, employing a six-well plate, containing $2 \mathrm{~mL}$ of complete DMEM medium and using a 24 X $24 \mathrm{~mm}$ sterile cover slip. Cells were incubated at $37^{\circ} \mathrm{C}$, with $5 \% \mathrm{CO} 2$ atmosphere, until a confluency of $80 \%$ (about 24 hours). The medium was removed and cells were washed three times with sterile PBS at $37^{\circ} \mathrm{C}$ for 5 minutes. Cells were fixated with $4.0 \%$ formalin, diluted in PBS, at $4^{\circ} \mathrm{C}$ for 30 minutes and then washed three times with $\mathrm{PBS}$ at $37^{\circ} \mathrm{C}$ for 5 minutes. Cells were permeabilized with $0.01 \%$ Triton X-100 (Sigma, Germany), diluted in $\mathrm{PBS}$, at $4^{\circ} \mathrm{C}$ for 10 minutes. Cells were washed once with PBS and incubated overnight at $4^{\circ} \mathrm{C}$, in a moist chamber, with the polyclonal anti-STAT3 Y705 antibody produced in rabbit (Immuny, Campinas, Brazil) at 1:50 dilution in 1.0\% BSA. The material was washed three times with PBS under described conditions and then incubated at $4^{\circ} \mathrm{C}$ for 3 hours with antirabbit IgG conjugated with FITC secondary antibody (Sigma, Germany) at 1:200 dilution in 1.0\% BSA. A cutaneous papilloma 01 cell line, incubated only with secondary antibody, was used as negative control. Cells were washed three times with PBS and cover slips were mounted on slides, using $20 \mu \mathrm{L}$ of ProLong Gold (Invitrogen, Carlsbad, USA) with DAPI. Slides were analyzed in Axio Scope A1 fluorescent microscope (Carls Zeiss, Germany) under total magnification of 400X.

Flow cytometry: Cell lines were seeded in culture flasks of 25 $\mathrm{cm} 2$ with $5.0 \mathrm{~mL}$ of complete DMEM medium. Cells were subjected to monolayer disaggregation with $2 \mathrm{~mL}$ of EDTA solution, centrifuged at $400 \mathrm{~g}$ for 5 minutes. Cells were transferred to $1.5 \mathrm{~mL}$ polypropylene tubes and fixed in $1.0 \mathrm{~mL}$ of $1.0 \%$ formalin solution at $4^{\circ} \mathrm{C}$ for 2 hours.
The material was centrifuged under described conditions, and washed twice with $1.0 \mathrm{~mL}$ of PBS at $4^{\circ} \mathrm{C}$ to remove the formalin residues. Cell were incubated with $1.0 \%$ BSA at $4^{\circ} \mathrm{C}$ for 20 minutes, washed once with PBS, and incubated overnight at $4^{\circ} \mathrm{C}$ with $1.0 \mu \mathrm{L}$ of anti STAT3 Y705 primary antibody (Immuny, Campinas, Brazil). Cells were centrifuged and washed twice with PBS at $4^{\circ} \mathrm{C}$. The material was incubated at $4^{\circ} \mathrm{C}$ for 2 hours with anti-rabbit IgG1 conjugated with Alexa Fluor 633 secondary antibody (Invitrogen, Carlsbad, USA) at 1:200 dilution. Next, cells were washed with PBS, centrifuged and resuspended in $100 \mu \mathrm{L}$ of PBS. The material was analyzed in Accuri C6 cytometer (BD Bioscience, USA). A total of 10,000 events were analyzed. Results were analyzed in FlowJo software (TreeStar, Oregon, USA). Analyses were based on the percentage of immunostained cells and fluorescence median, as proposed elsewhere $(47,48)$. Two controls were used: (1) normal skin cell line not treated with any antibody and (2) cutaneous papilloma treated only with secondary antibody (Alexa Fluor 633).

\section{Results}

\section{Molecular identification of BPV DNA sequences}

PCR results showed the presence of BPV DNA sequences in primary cultures derived from cutaneous papilloma (papilloma 01), fibropapilomas (papillomas 02 and 03) and esophageal carcinoma, but not in normal skin (figure 1). Results also show the maintenance of BPV DNA sequences along the six passages analyzed in primary cultures derived from cutaneous papilloma, fibropapilloma and (figure 1).

\section{Cell cycle analysis}

Analysis of division cell kinetics pointed out an increase in cell percentage in S and/or G2-M phases in BPV-infected cells in relation to normal skin (figure 2 ), suggesting that the virus can induce the hyperproliferation in vitro.

\section{Mitochondrial membrane potential $(\Delta \Psi \mathrm{m})$ anal- ysis}

Results showed that cutaneous papilloma present an oxidative metabolism similar to those verified in normal skin (figure 3 $\mathrm{A}$ and $\mathrm{B})$, being observed the $\Delta \Psi \mathrm{m}$ maintenance. By the opposite, it was verified a reduction in cell percentage in fibropapilomas (papilloma 02 and 03) and esophageal carcinoma (figure $3 \mathrm{~A}$ and $\mathrm{B}$ ), indicating a loss of $\Delta \Psi \mathrm{m}$. Papilloma 02 (fibropapilloma) and esophageal carcinoma cells showed the highest MFI (figure 3C). Statistical differences among these cell lines and normal skin, papilloma 01 and 03 were also verified by the Bonferroni's multiple comparison test ( $\mathrm{p}<0.0001)$. These results suggest that dermis involvement is associated to energy metabolism switch.

We also analyzed the action of BPV-1 E6 recombinant oncoprotein in the $\Delta \Psi \mathrm{m}$. Results of this analysis showed that the addition of BPV-1 E6 oncoprotein in normal skin (uninfected by BPV) promote the loss of $\Delta \Psi \mathrm{m}$ (figure 4 ). 

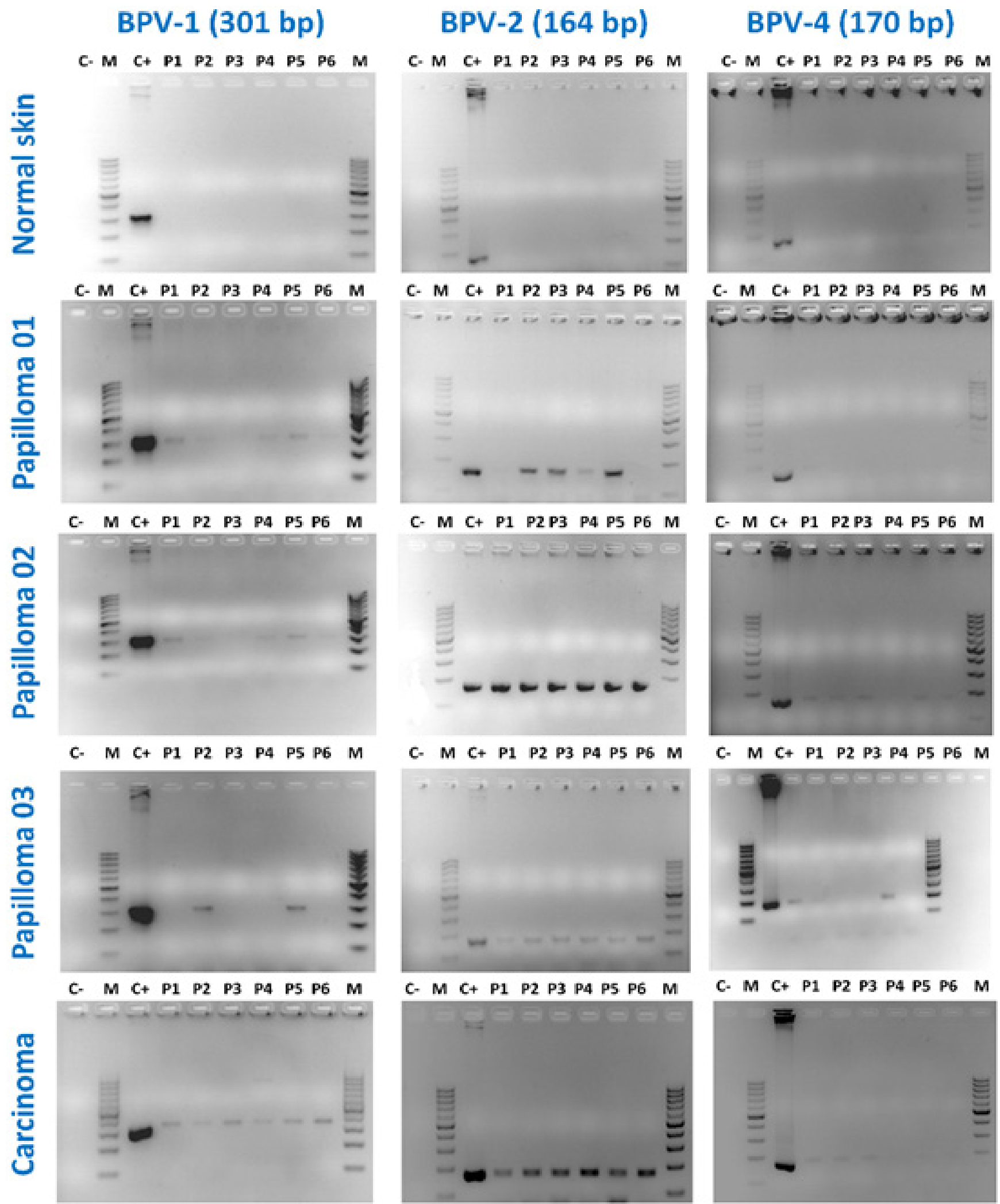

Figure-1: BPV DNA sequences identified by PCR 

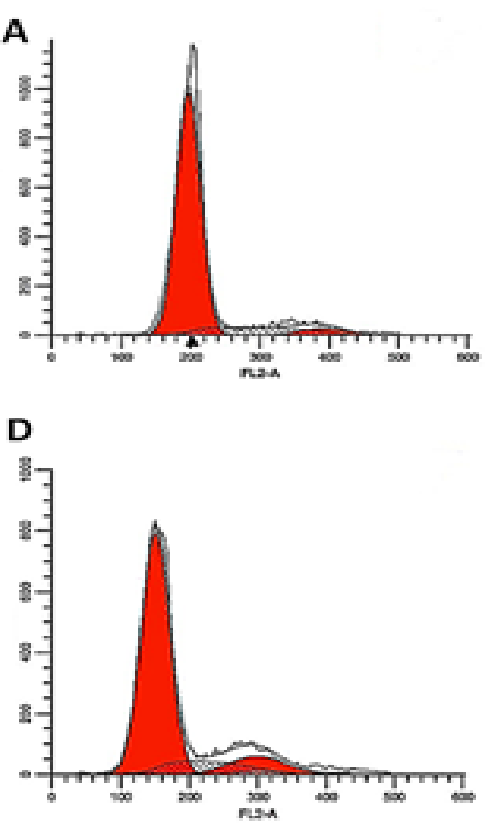

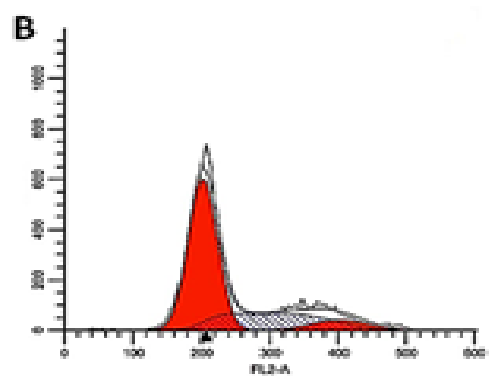

E

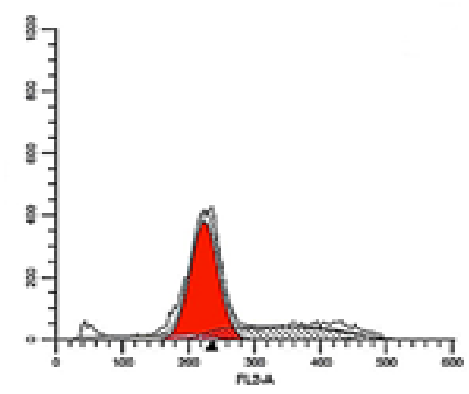

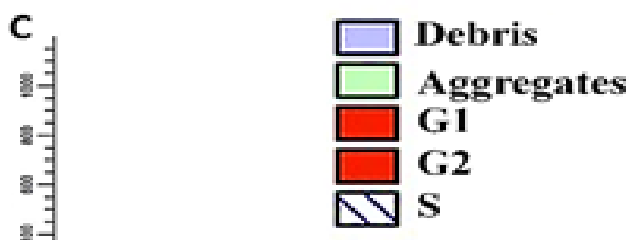

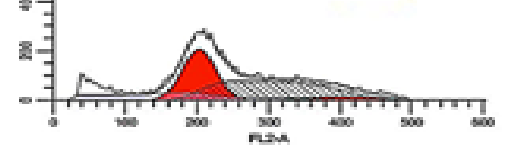

F Cell cycle

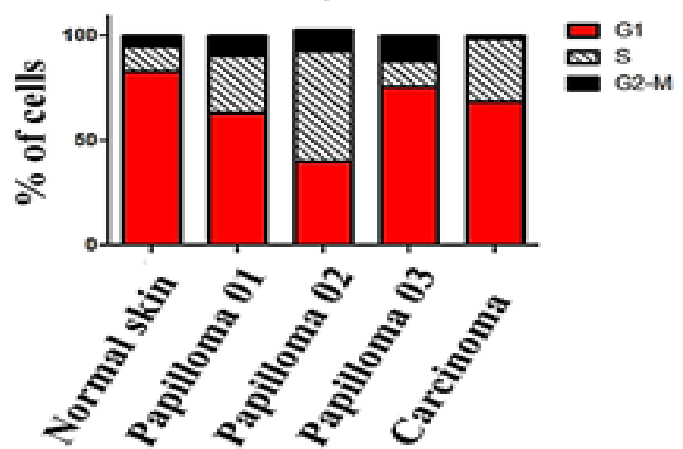

Figure -2: Cell cycle analysis by flow cytometry: normal skin (A), papilloma 01 (B), 02 (C), 03 (D), esophageal carcinoma (E) and cell cycle distribution (F). Results show a cell percentage increase in S (synthesis) and G2-M in all primary cultures derived from $\mathrm{BPV}$-infected lesions in relation to BPV-free normal skin cells.

\section{ROS production}

Results of DCFH-DA assay showed that all cells derived from BPV-infected lesions present high percentage of ROS-producing cells in relation to normal skin cell line (figure 5), however the esophageal carcinoma cells showed a restrict number of cells presenting oxidative metabolism in relation to papilloma and fibropapilloma cells (figure 5). Normal skin cells presented the highest MFI (figure 5), however restricted a few number of cells (figure 5). Statistical differences among the primary cultures were also verified by the Bonferroni's multiple comparison test $(\mathrm{F}=114.4, \mathrm{p}<0.005)$, except by the normal skin and esophageal carcinoma cell lines, which presented non statistical difference $(\mathrm{p}>0.05)$.

To verify the action of BPV-1 E6 oncoprotein in ROS production, normal skin cell lines were treated with the recombinant oncoprotein. Results of this analysis demonstrated that the addition of E6 oncoprotein increase the ROS-producing cell percentage (figure 6). Although the normal skin cells had showed the highest MFI (figure 6), the Kruskal-Wallis test did not reveal statistical differences among the groups ( $p=0.3679$ ).

\section{Comet assay}

Results of comet assay showed a high frequency of class 2 (maximum damage) nucleoids in cells derived from BPVinfected lesions in relation to normal skin (table 1, figure 7). Based on the comet score, it was performed the Kruskal-Wallis test, that revealed statistical difference among the primary cultures $(\mathrm{H}=20.1952$ and $\mathrm{p}=0.0005)$.
For this reason, it was performed the Dunn post hoc test (table 2), which showed that the esophageal carcinoma cells present the highest comet score (table 3, figure 7). The cutaneous papilloma 02 and 03 cell lines showed intermediate score values, whereas the cutaneous papilloma 01 presents scores similar to those verified in normal skin cell line (table 3 ). Linear regression showed the cell passages do not promotes DNA breaks, since Pearson coefficient of skin papilloma, fibropapilloma and esophageal carcinoma cells were smaller than 0.98 (figure 8).

\section{STAT3 Y705 immunodetection}

Results showed an increase in STAT3 Y705 expression levels in cells derived from cutaneous papilloma and fibropapilloma (figure 9). Although esophageal carcinoma and normal skin have showed similar expression levels of STAT3 Y705, it was verified a nuclear labelling of this nuclear transcription factor in esophageal carcinoma cells (figure 9). Both negative controls (immunofluorescence and flow cytometry) showed the absence of unspecific labelling. 


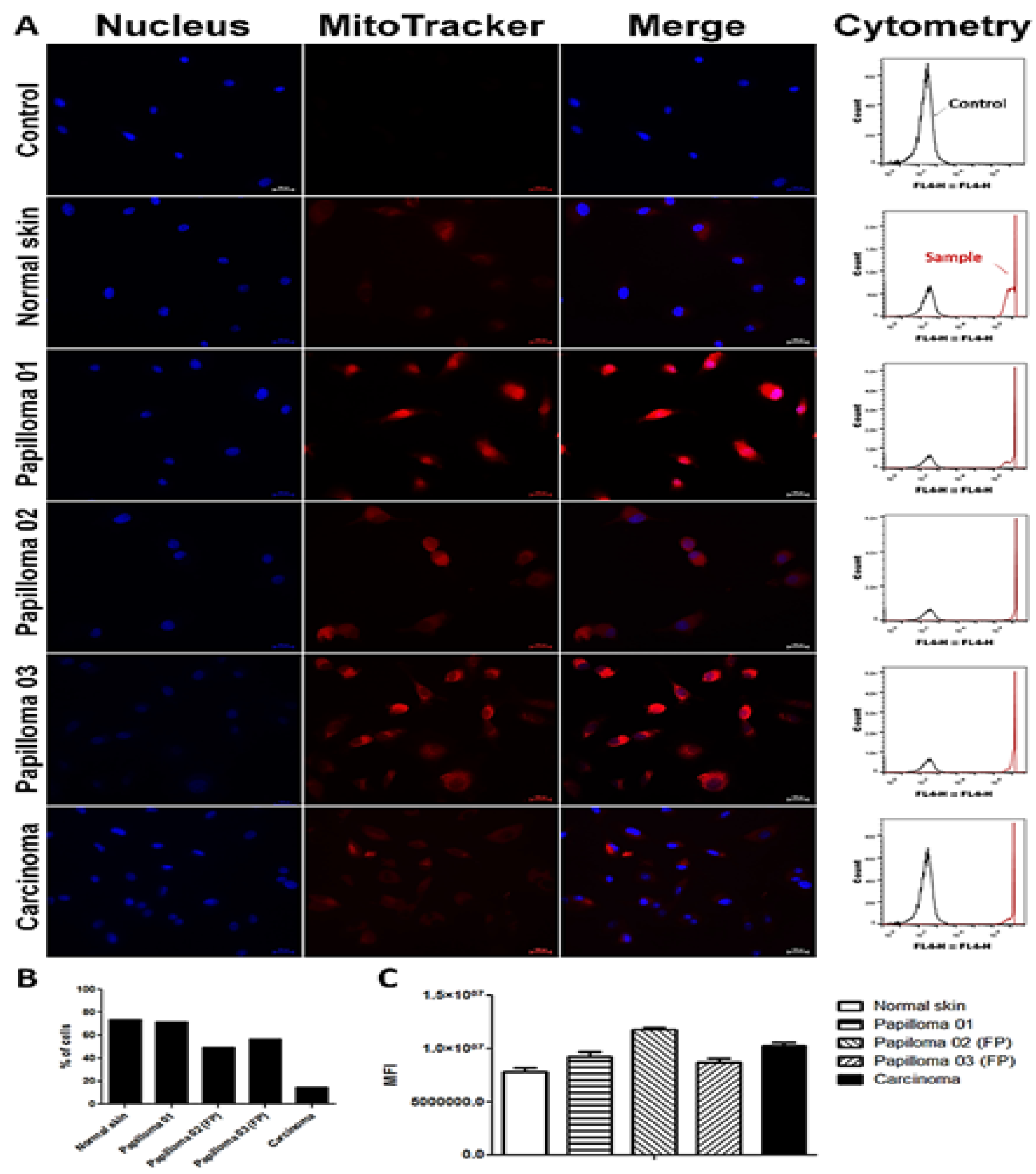

Figure -3: Analysis of BPV action on mitochondrial membrane potential $(\Delta \Psi \mathrm{m})$ deregulation by immunofluorescence and flow cytometry (FC): A) control presenting absence of fluorescent signal in cutaneous papilloma cell line not treated with MitoTracker probe, MitoTracker labelling in normal skin, papillomas and esophageal carcinoma cells in second passage. Histograms based on cell percentage labelled with MitoTracker probe (B) and the median of fluorescent intensity (MFI) + standard deviation (C). Results show a reduction in cell percentage with oxidative metabolism in fibropapilloma (FP) and esophageal carcinoma cell lines, suggesting the activation of aerobic glycoslysis. Bonferroni's multiple comparison analysis based on MFI showed an increase in MFI of papilloma 02 and esophageal carcinoma cells, suggesting an energy compensatory mechanism. Total of 10,000 events analyzed. Scale bar of $100 \mu \mathrm{m}$. Flow cytometry graphs showing number of cells (Y axis) and fluorescent intensity in FL4 channel (X axis). 


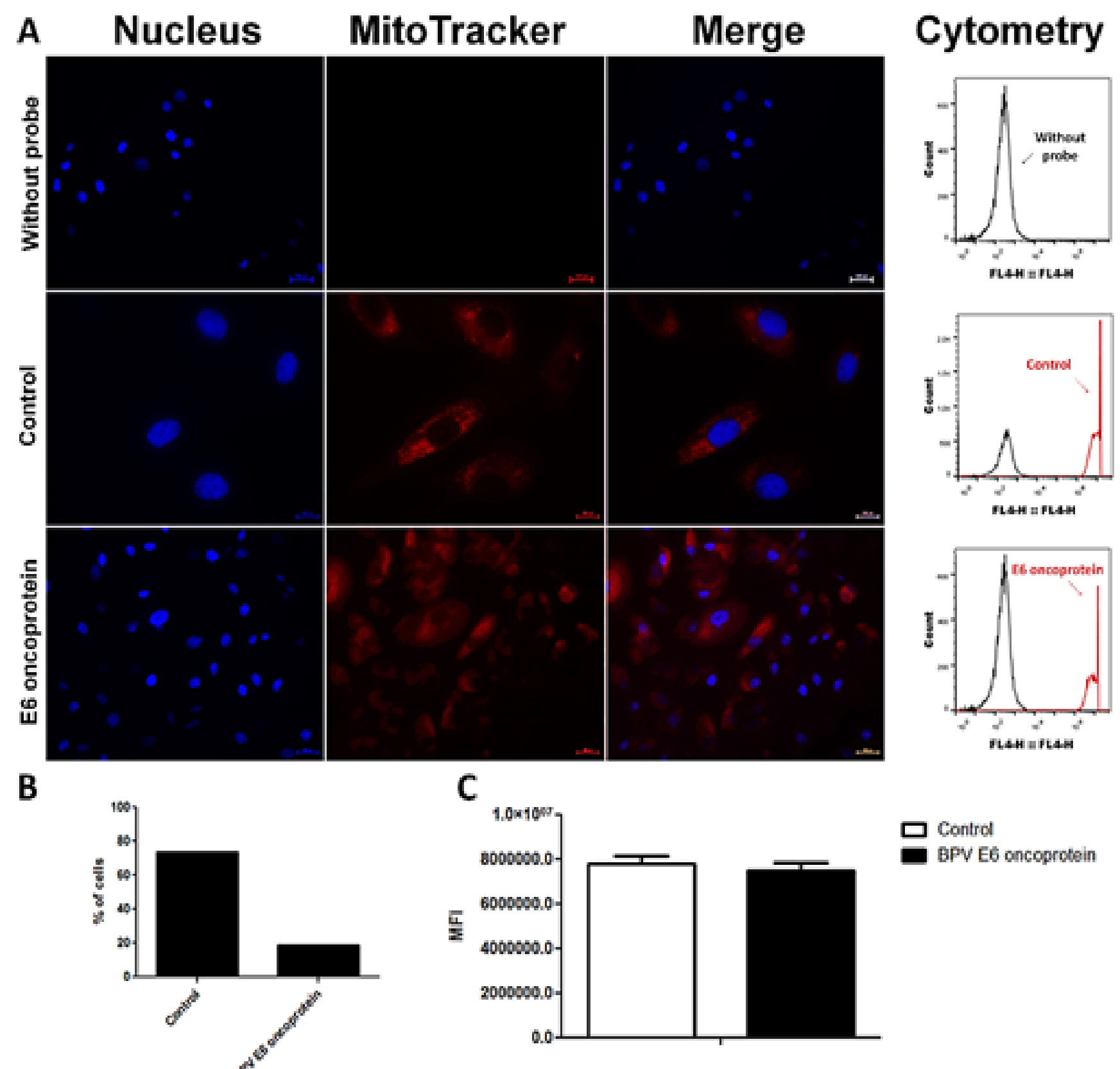

Figure- 4: Analysis of BPV E6 oncoprotein on mitochondrial membrane potential $(\Delta \Psi \mathrm{m})$ deregulation by immunofluorescence and flow cytometry (FC). A) negative control (without probe) presenting absence of fluorescent signal in cutaneous papilloma cell line not treated with MitoTracker probe; normal skin cell lines normal skin cell line (uninfected by BPV) and normal skin cell line treated with $1 \mu \mathrm{g} / \mathrm{mL}$ of BPV-1 E6 recombinant oncoprotein. Histogram based on cell percentage labelled with MitoTracker probe (B) and median of fluorescent intensity $(\mathrm{MFI})+$ standard deviation $(\mathrm{C})$. Results show a reduction of mitochondrial membrane potential after the treatment with BPV-1 E6 oncoprotein (B), however, without reduce the MFI (C) in cells expressing oxidative metabolism. 


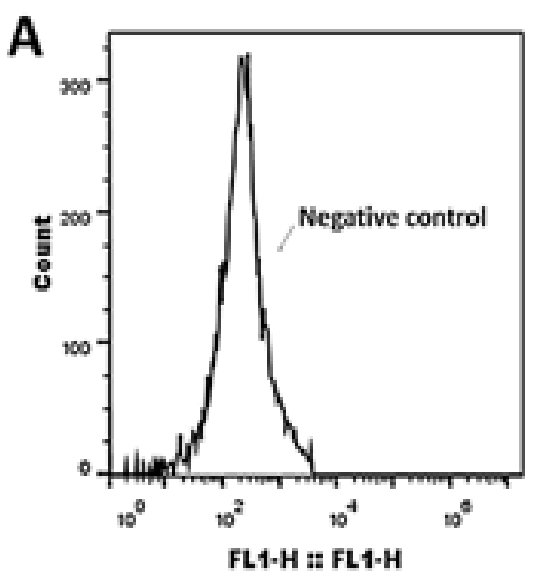

D

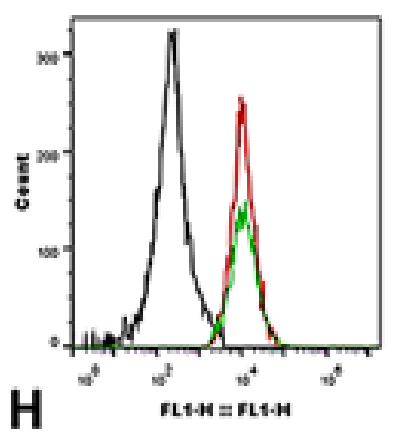

B

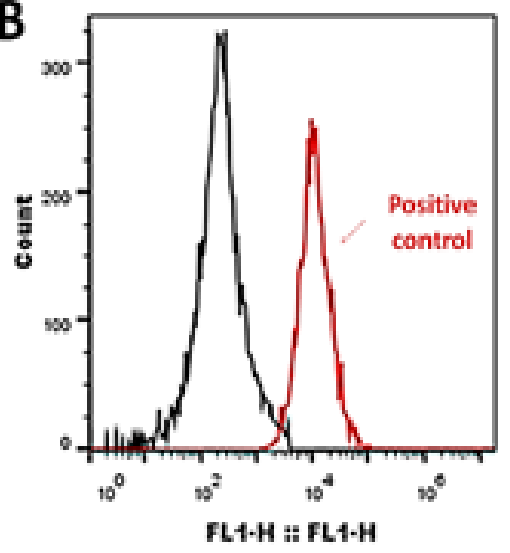

$\mathbf{F}$

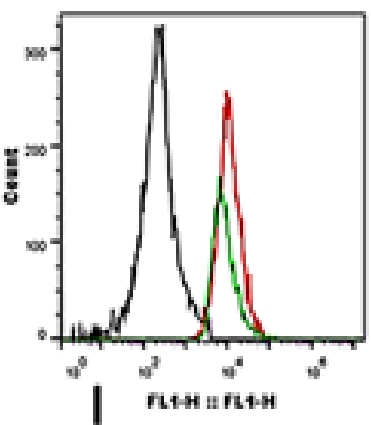

C

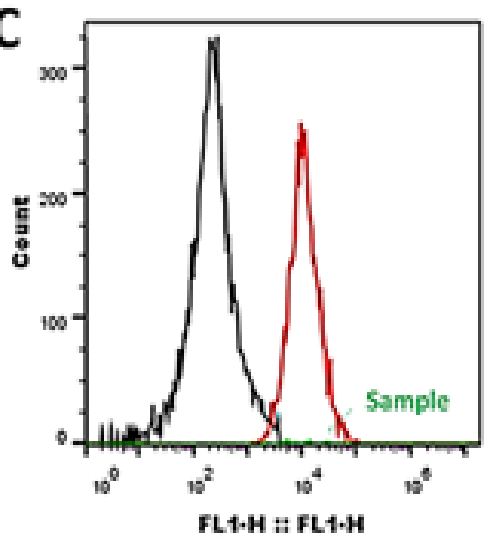

G

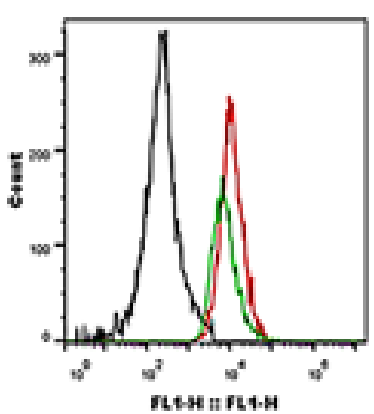

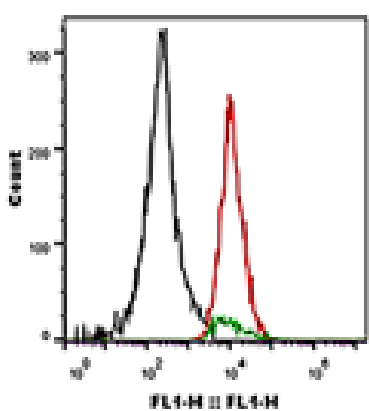
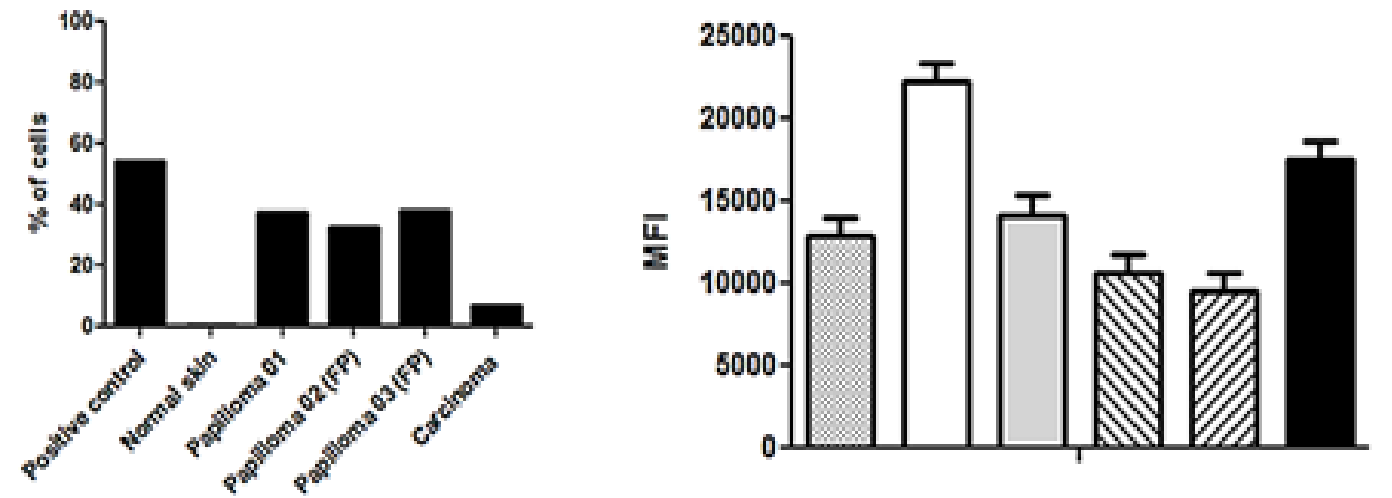

Figure- 5: Levels of reactive oxygen species (ROS) observed on five cell lines. A) flow cytometry showing absence of unspecific labelling in cutaneous papilloma cells not treated with the DCFH-DA probe (negative control) and ROS production in: B) normal skin cells treated with $1 \mathrm{mM}$ of $\mathrm{H} 2 \mathrm{O} 2$ and incubated with probe (positive control), C) normal skin, D) cutaneous papilloma 01, E) papilloma 02 (FP - fibropapilloma), F) papilloma 03 (FP - fibropapilloma) and G) esophageal carcinoma cells. Histograms based on cell percentage labelled with DCFH-DA probe $(\mathrm{H})$ and median of fluorescent intensity (MFI) + standard deviation (I). Results show that the normal skin cells presented the highest ROS production, verified by the mean of fluorescence intensity (MFI) (I), but restricted a fewest number of cells $(\mathrm{H})$. Papillomas cells showed intermediate levels of ROS (I), but in a high cell percentage, reinforcing the energy compensatory mechanism. Total of 10,000 events analyzed. Scale bar of $100 \mu$ m. Flow cytometry graphs showing number of cells (Y axis) and fluorescent intensity in FL1 channel (X axis). Cells analyzed in second passage (P2). 
A

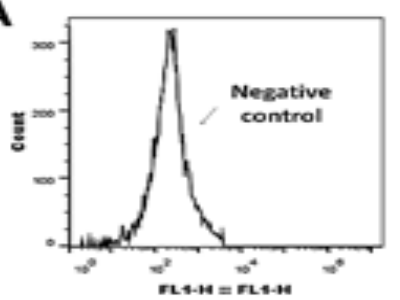

E

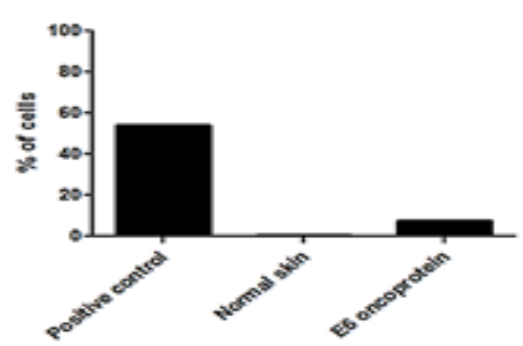

B

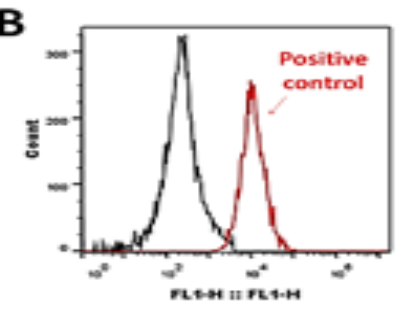

$\mathbf{F}$
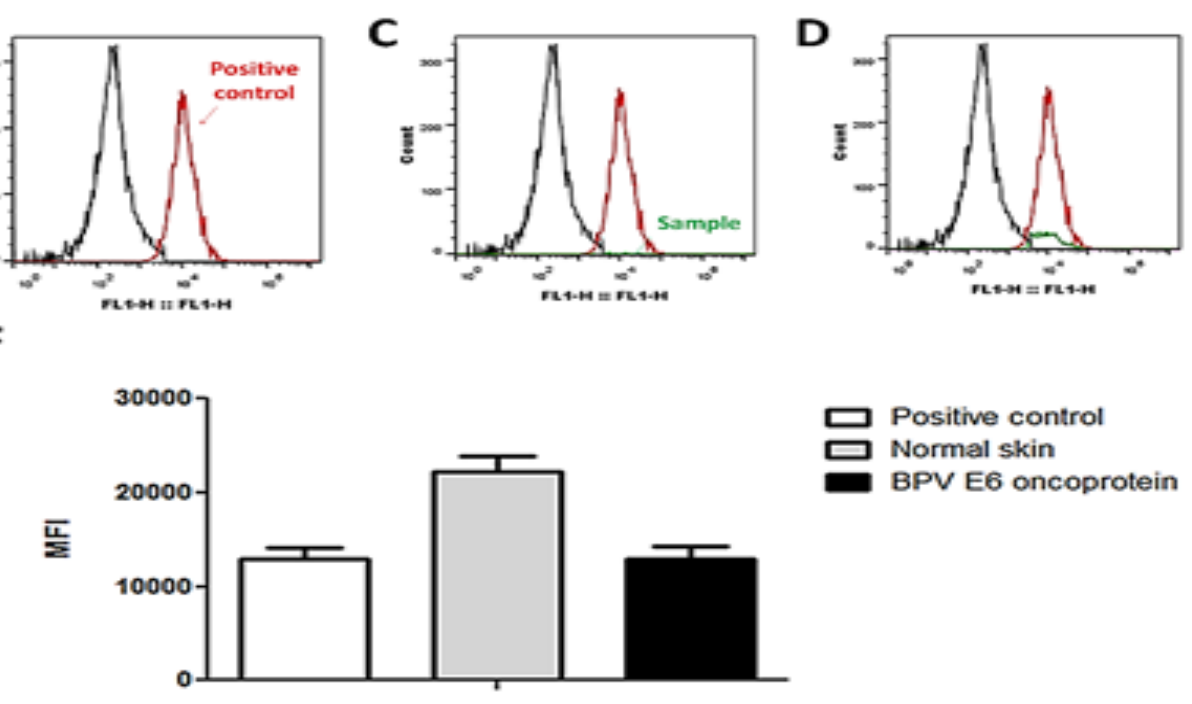

Figure- 6: Levels of reactive oxygen species (ROS) observed after E6 oncoprotein addition. A) normal skin cell line (uninfected by BPV) not incubated with DCFH-DA probe (negative control), showing absence of labelling, B) normal skin cell line treated with 1 $\mathrm{mM}$ of $\mathrm{H} 2 \mathrm{O} 2$ and incubated with probe, showing ROS formation (positive control), C) normal skin cell line only incubated with probe, showing reduced ROS production as a consequence of normal oxidative metabolis, D) normal skin cell line treated with 1 $\mu \mathrm{g} / \mathrm{mL}$ of BPV-1 E6 recombinant oncoprotein. Histogram based on ROS-producing cell percentage (E) and median of fluorescent intensity (MFI) + standard deviation (F). Results show an increase in ROS production in cells treated with BPV-1 E6 oncoprotein. Total of 10,000 events analyzed. Scale bar of $100 \mu \mathrm{m}$. Flow cytometry graphs showing number of cells (Y axis) and fluorescent intensity in FL1 channel (X axis). Cells analyzed in second passage (P2).
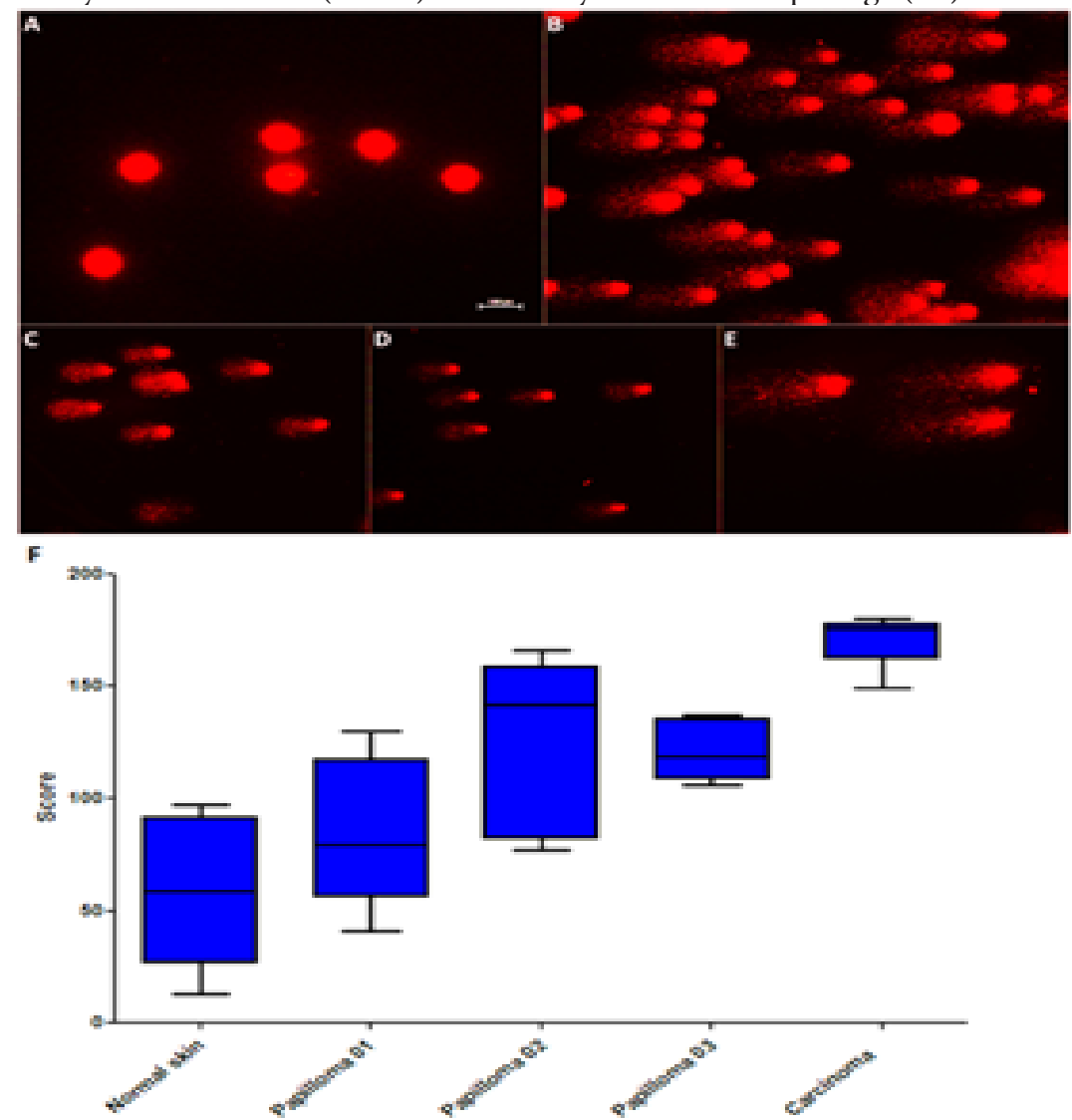

Figure -7: Analysis of clastogenic potential of BPV by comet assay. A) nucleoids showing absence of DNA damage (class 0 ) observed in normal skin (uninfected by BPV), nucleoids showing maximum level of DNA damage (class 2), observed in cutaneous papilloma 01 (B), 02 (C), 03 (D) and esophageal carcinoma cell lines (F). G) Boxplot showing maximum, minimum and median of comet scores, demonstrating high levels of clastogenesis in esophageal carcinoma cell line. 

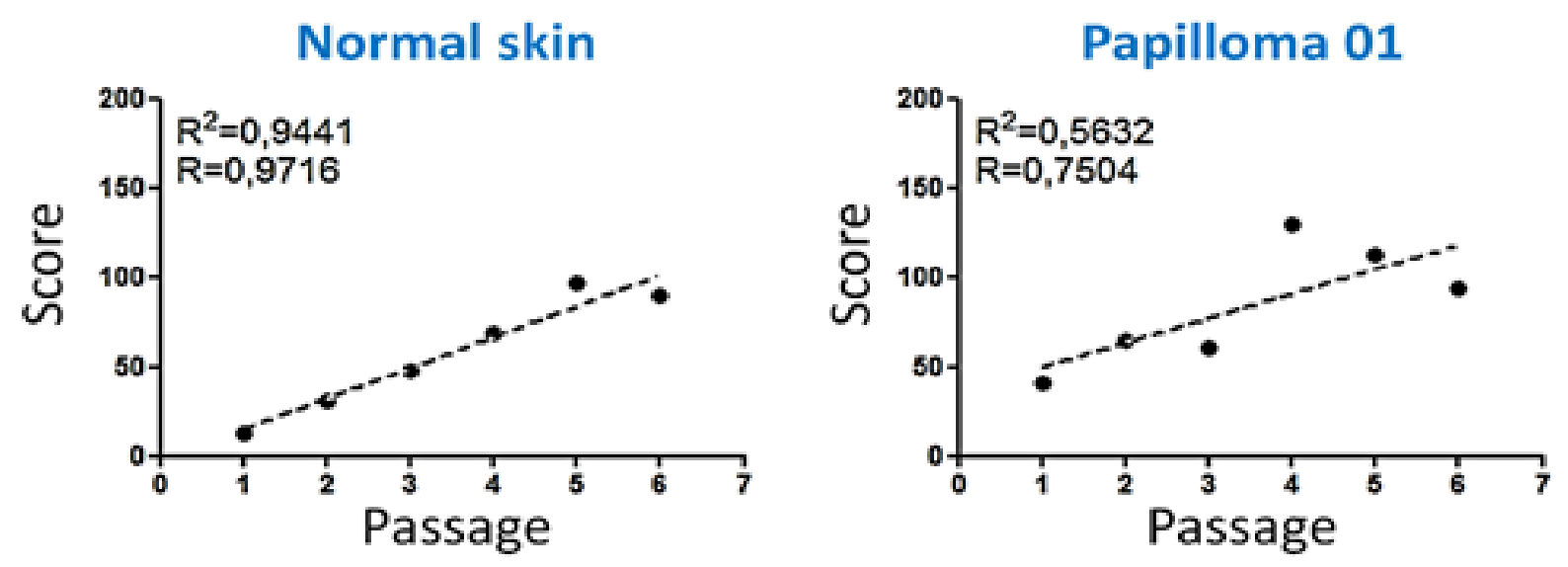

Papilloma 02 (FP)

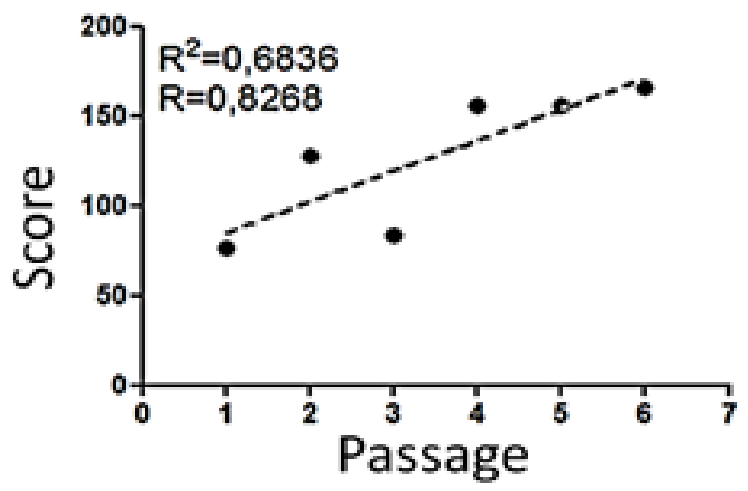

\section{Papilloma 03 (FP)}

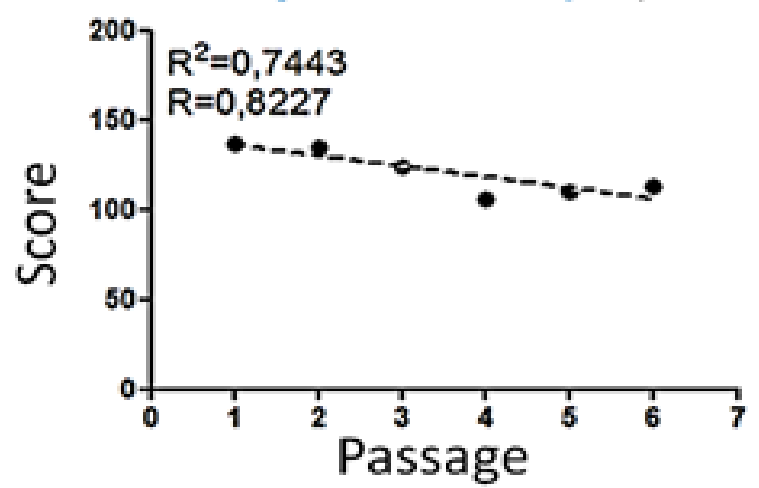

\section{Esophageal carcinoma}
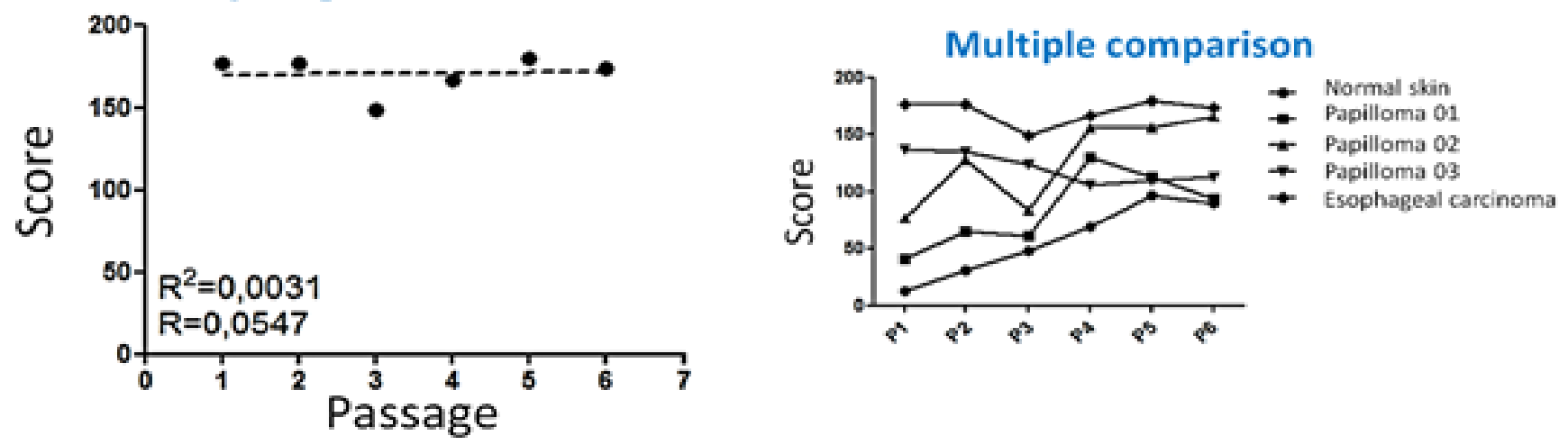

Figure-8: Linear regression of comet score 


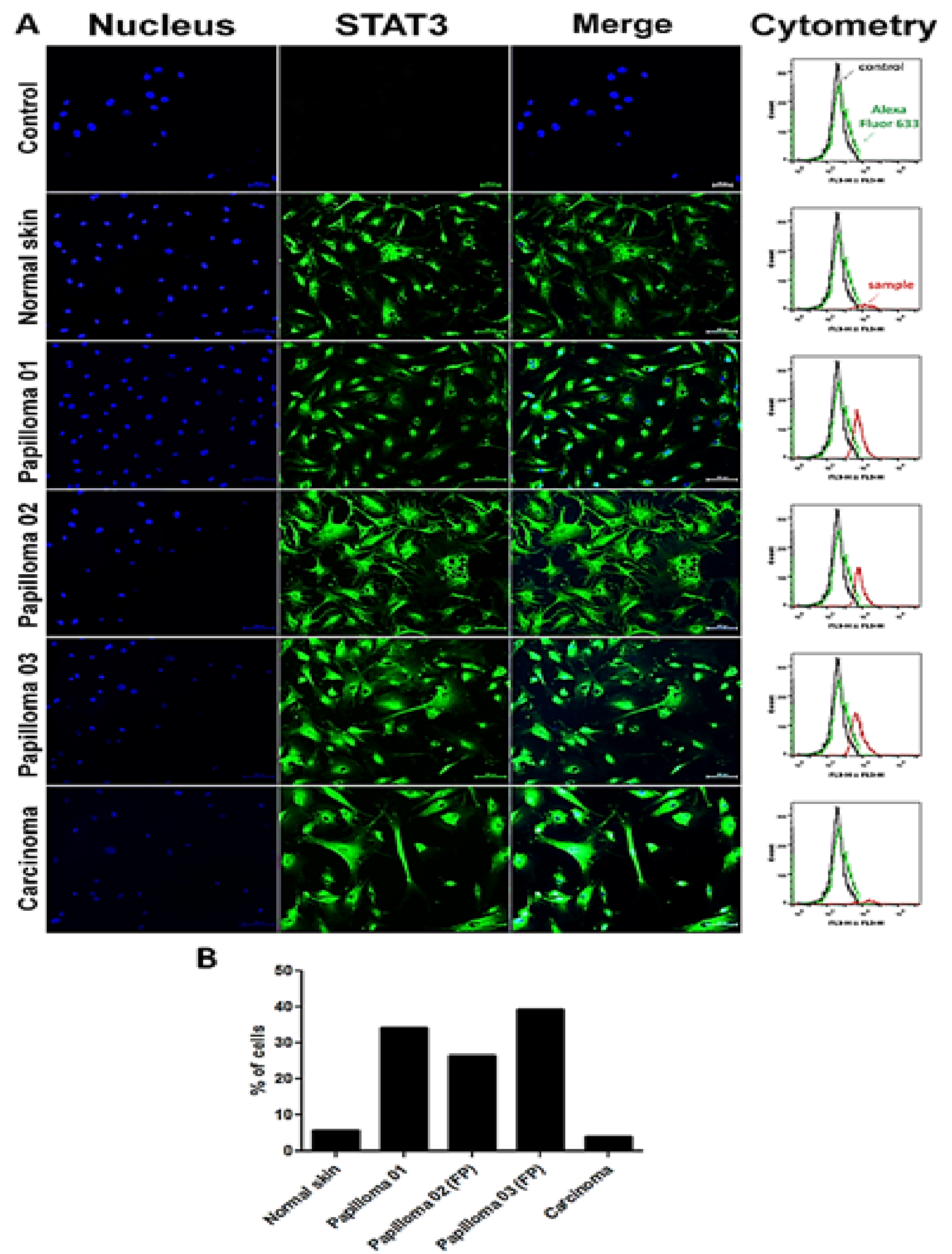

Figure-9: Analysis of STAT3 Y705 expression. A) photomicrograph and flow cytometry showing absence of unspecific labelling in cutaneous papilloma cell line only treated with secondary antibody (Alexa Fluor 633) (control) and normal skin cells not treated with any antibody. Results show the immunodetection of STAT3 activated in nucleus of cutaneous papilloma (papilloma 01), fibropapilloma (papilloma 02 and 03) and esophageal carcinoma, but not in normal skin cells. Histograms based on STAT3 Y705-expressing cell percentage (B) Results show a high STAT3-expressing cell percentage in both papilloma and fibropapilloma (FP) cells. Esophageal carcinoma and normal skin cells show the similar levels of expression of STAT3, however, it is verified the nuclear immunodetection of STAT3 in esophageal carcinoma, indicating the activation of this nuclear transcription factor. Total of 10,000 analyzed events. FP - fibropapilloma. Scale bar of $100 \mu \mathrm{m}$. Flow cytometry graphs showing number of cells (Y axis) and fluorescent intensity in FL1 channel (X axis). 


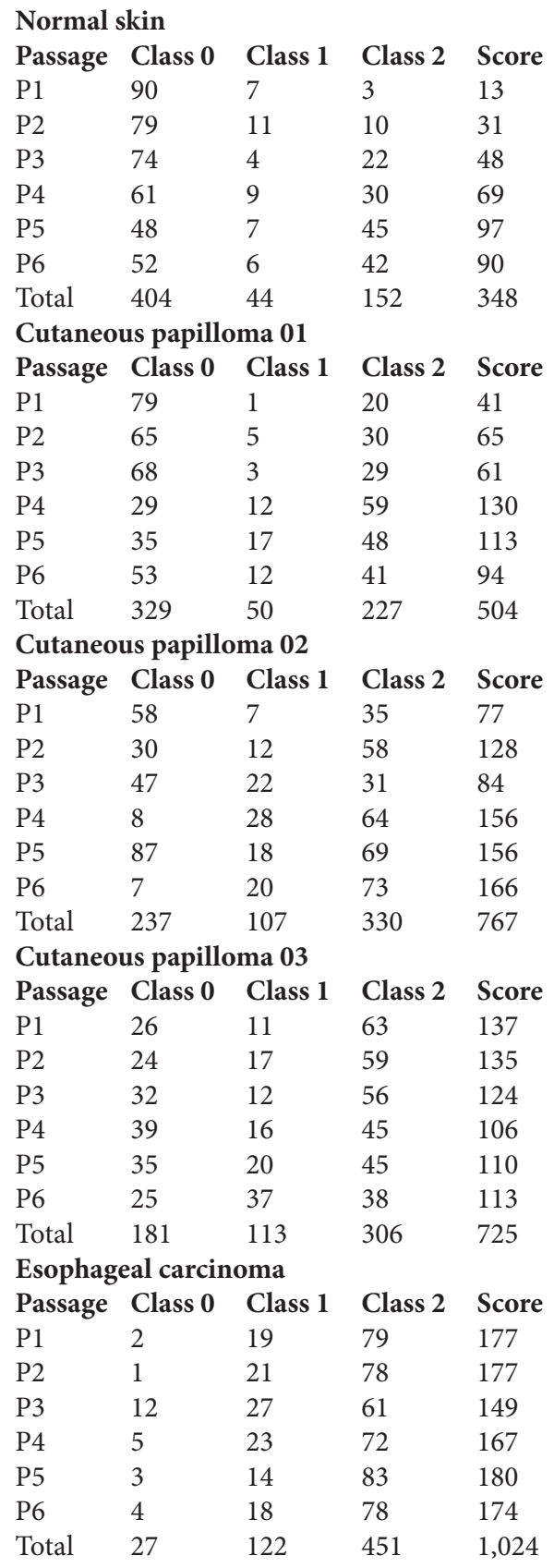

Table-1: Comet assay results

\section{Discussion}

In this study, we identified DNA sequences of at least one BPV type in cutaneous papilloma, fibropapilloma and esophageal carcinoma cell lines, but not in normal skin cell line (figure 1). These sequences were observed along all six cell passages analyzed, indicating a co-infection for BPV-1, 2 (Deltapapillomavirus) and 4 (Xipapillomavirus) (figure 1). The co-infection has been frequently described in clinical samples of papillomas and fibropapilomas $[49,50]$. However, the co-infection by BPV-1 and 2 in esophageal carcinoma suggest that the fibrotropism of these viruses can contribute to the tumor microenvironment deregulation, favoring the cancer initiation.
The presence and maintenance of DNA sequences of BPV-1 and 2 in primary culture of cutaneous papilloma, esophagus papilloma and urinary bladder cells were already described in the literature $[18,19]$. These data suggest that the in vitro systems are additional and useful model to study the biology of BPV, as discussed by Campos et al. [18].

The analysis of cell cycle showed a high percentage of BPVinfected cell in S and/or G2-M phases (figure 2), demonstrating the hyperproliferative action of BPV in vitro. The hyperproliferative action of BPV is responsible for the acanthosis verified in histopathological analysis $[49,51,52]$. This effect can be attributed to the combined action of E5, E6 and E7 oncoproteins. The transmembrane oncoprotein E5 is able to bind to the platelet-derived growth factor receptor beta (PDGF $\beta R$ ), inducing its dimerization [53]. This action activates different kinases (A-cdk2, MAPK, JNK, PI3K and c-Src) that stimulate the $\mathrm{S}$ phase entry [53]. The E6 oncoprotein promotes the Foxhead box M1(FOXM1) transcription factor activation, resulting in B1 and D1 cyclin expression [54]. Moreover, currently we described that the BPV-1 E6 oncoprotein has a hyperproliferative action homologous to E7 oncoprotein [44]. The E7 oncoprotein promotes the $\mathrm{pRb}$ phosphorylation, resulting in E2F transcriptional factor release and cell proliferation. These actions are crucial to provide DNA polymerases necessary to BPV replication.

However, the replication of both host cell and BPV genome demands high levels of ATP, since the BPV E1 (helicase) requires one ATP molecule for each nucleotide hydrolyzed along the double-strand DNA opening [55]. Moreover, the viral DNA packaging requires $0.8-2.5 \mathrm{kcal} / \mathrm{mol}$ to promote the viral chromatin condensing, which is $70 \%$ more condensed than eukaryotic chromatin [55]. For these reason, it is expected that BPV-infected cells increase the ATP synthesis and, therefore, the $\Delta \Psi \mathrm{m}$. In this sense, we verified that papilloma cells present the same MitoTracker-labelled cell percentage of the normal skin (figure 3). But, interesting, we verified a loss of $\Delta \Psi \mathrm{m}$ in both fibropapilloma and esophageal carcinoma cells (figure 3). These data suggest that dermal involvement has an important role in pathogenesis of cancer progression. In this sense, Potocki et al. [14] demonstrated that BPV-1-positive sarcoid-derivate fibroblasts present a $\Delta \Psi \mathrm{m}$ depletion, suggestion that the energy production is compensated by cytosolic glycolysis, suggesting that BPV-mediated metabolic deregulation can lead to "Warburg effect".

Depolarization of mitochondrial membrane is common feature of cell death. In this sense, at the same time that we observed the loss of $\Delta \Psi \mathrm{m}$ in fibropapilloma and esophageal carcinoma cells, we verified an increase in MFI, which was confirmed by the Bonferroni's test (figure 3 ). These data reinforce the energy compensatory mechanism proposed by Potocki et al. [14]. In addition, our data suggest that metabolic alterations are associated to the virus persistence-associated neoplasm progression. 


\begin{tabular}{lllll}
\hline Comparition & Post difference & Z calculated & Critical Z & p \\
Normal skin and Papilloma 01 & 3.9167 & 0.7706 & 2.807 & $\mathrm{~ns}$ \\
Normal skin and Papilloma 02 & 11.8333 & 2.3282 & 2.807 & $\mathrm{~ns}$ \\
Normal skin and Papilloma 03 & 10.7500 & 2.1150 & 2.807 & $\mathrm{~ns}$ \\
Normal skin and esophageal carcinoma & 21.0000 & 4.1317 & 2.807 & $<0.05$ \\
Papilloma 01 and Papilloma 02 & 7.9167 & 1.5576 & 2.807 & $\mathrm{~ns}$ \\
Papilloma 01 and Papilloma 03 & 6.8333 & 1.3444 & 2.807 & $\mathrm{~ns}$ \\
Papilloma 01 and esophageal carcinoma & 17.0833 & 3.3611 & 2.807 & $<0.05$ \\
Papilloma 02 and Papilloma 03 & 1.0833 & 0.2131 & 2.807 & $\mathrm{~ns}$ \\
Papilloma 02 and esophageal carcinoma & 9.1667 & 1.8035 & 2.807 & $\mathrm{~ns}$ \\
Papilloma 03 and esophageal carcinoma & 10.2500 & 2.0167 & 2.807 & $\mathrm{~ns}$
\end{tabular}

Table-2: Results of post hoc Dunn test ns - non significative statiscal difference

$\begin{array}{llllll}\text { Passage } & \text { Normal skin } & \text { Papilloma 01 } & \text { Papilloma 02 } & \text { Papilloma 03 } & \text { Esophageal carcinoma } \\ \text { P1 } & 13^{\mathrm{a} *} & 41^{\mathrm{a}} & 77^{\mathrm{a}}, \mathrm{b} & 137^{\mathrm{a}}, \mathrm{b} & 177 \mathrm{~b} \\ \text { P2 } & 31^{\mathrm{a}} & 65^{\mathrm{a}} & 128^{\mathrm{a}}, \mathrm{b} & 135^{\mathrm{a}}, \mathrm{b} & 177 \mathrm{~b} \\ \text { P3 } & 48^{\mathrm{a}} & 61^{\mathrm{a}} & 84^{\mathrm{a}}, \mathrm{b} & 124^{\mathrm{a}}, \mathrm{b} & 149 \mathrm{~b} \\ \text { P4 } & 69^{\mathrm{a}} & 130^{\mathrm{a}} & 156^{\mathrm{a}}, \mathrm{b} & 106^{\mathrm{a}}, \mathrm{b} & 167 \mathrm{~b} \\ \text { P5 } & 97^{\mathrm{a}} & 113^{\mathrm{a}} & 156^{\mathrm{a}}, \mathrm{b} & 110^{\mathrm{a}}, \mathrm{b} & 180 \mathrm{~b} \\ \text { P6 } & 90^{\mathrm{a}} & 94^{\mathrm{a}} & 166^{\mathrm{a}}, \mathrm{b} & 113^{\mathrm{a}}, \mathrm{b} & 174 \mathrm{~b}\end{array}$

Table-3: Statistical results of comet assay

${ }^{*}$ numbers followed by equal letters indicate the absence of significate statistical differences

Evidences of mutagenic potential of BPV have been described since 1998 [10-12,19]. However, up to date, the DNA damages verified in PVs-infected cells have been attributed to the replication fork stress resulting of the hyperproliferative action of E5, E6 and E7 oncoproteins [13]. In this sense, the high levels of ROS observed in papilloma and fibropapilloma can be discussed as an additional source of mutations. This because ROS can promote the DNA oxidation, leading to DNA breaks [5] observed in papillomavirus-infected cells lines (table 1, figure 7 ), as well as those described in literature [10-14,19]. Similar results were also verified in HPV infected cells, in which it was demonstrated that the HPV-16 E6 ${ }^{\star}$-induced oxidative stress and DNA breaks, which are necessary to HPV integration $[15,16]$.

Based on these data, we analyzed the action of BPV-1 E6 recombinant oncoprotein in glycolytic metabolism. Results of these analysis showed that the BPV E6 oncoprotein lead to $\Delta \Psi \mathrm{m}$ loss (figure 4). However, curiously, we observed an increase in ROS production in cells treated with E6 oncoprotein (figure 6), suggesting a paradoxical effect. This effect can be attributed to the E6-mediated downregulation of SOD2 and GPx antioxidant enzymes (figure 10) $[15,16]$, resulting in hydrogen peroxide (ROS) production. These results suggest that BPV E6 oncoprotein has a pro-oxidant action homologous to those verified in HPV-16 E6 ${ }^{\star}$ [15], hepatitis C virus (HCV) NS3 and NS5A [56], Epstein-Barr virus (EBV) EBNA1 [57] and dengue virus (DENV) NS1 proteins [58].
Considering the papillomavirus infection persistence, naturally verified in both human and bovines, the metabolic deregulation induced by E6 oncoprotein can contribute to cell transformation. These findings indicate that E6 oncoprotein is a biotechnological target for anti-cancer drug design, since pro-oxidant molecules have revealed a high pharmaceutical valor, once therapies based on anti-oxidant agents (resveratrol and vitamin E) demonstrated to reduce the DNA damages associated to E6-mediated ROS production [16]. However, in high levels, ROS can lead to apoptosis. For these reason, cancer cells direct their metabolism to glycolytic pathway, avoiding the excessive ROS production that could result in apoptosis. In this sense, we verified an expressive reduction in $\Delta \Psi \mathrm{m}$ and ROS production (figure 5) in cells derived from esophageal cancer (figure 3 ), suggesting the activation of aerobic glycolysis, which is considered a cancer hallmark.

We observed the activation and nuclear translocation of STAT3 in cells derived from BPV-infected lesions (figure 9). Similar results were also verified in cells infected by other oncogenic viruses, such as: human T-leukemia virus (HTLV) [59], HBV and HCV [60]. These data suggest that the activation of STAT3 in a common pathway observed in the oncogenic process associated to infectious agents. 

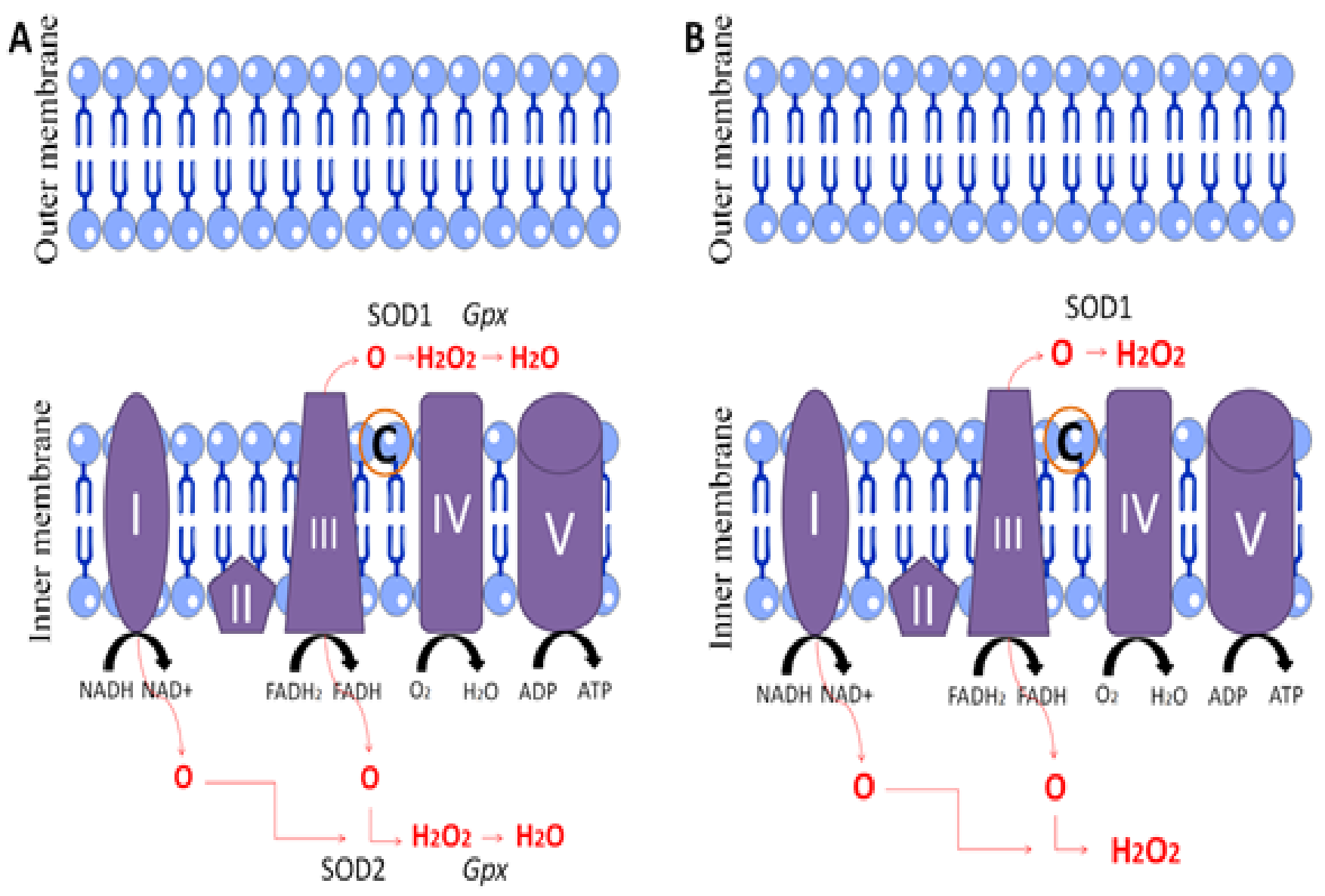

Figure-10: Downregulation of SOD2 and GPx antioxidant enzymes

A) Under normal conditions, the singlet oxygen produced by the mitochondrial complex is converted to hydrogen peroxide by the superoxide dismutase 1 (SOD1) or 2 (SOD2) and, the hydrogen peroxide is converted to water molecule by the GPx enzyme. B) However, the E6 oncoprotein expression leads to the SOD2 and GPx downregulation, reducing the catalysis of singlet oxygen and hydrogen peroxide (ROS). However the electron flux is conserved, avoiding the cytochrome c release and, therefore, conferring an anti-apoptotic stimulus.

The nuclear immunodetection of STAT3 Y705, verified in BPV-infected cells (figure 8), has clinical implications, since STAT3 can induce the D1 and D3 cyclin expression, promoting the $\mathrm{S}$ phase entry, necessary to the virus replication. In this sense, the STAT3 action can contributes to the cell proliferation increase verified in BPV-infected cells (figure 2). However, the activation of STAT3 can lead the overexpression of glucose receptor GLUT1 [46]. This action affects the complex I and II of mitochondrial electron transporter chain [46], reducing the OXPHOS [46]. Thus, these actions can lead to the reduction of the $\Delta \Psi \mathrm{m}$ and ROS production verified in the esophageal carcinoma cell line (figure 3 and 5). In this sense, our results suggest that the STAT3 action can lead to the Warburg effect. In summary, our results demonstrate that primary cultures derived from papillomavirus-infected lesions are useful model to study the energy metabolism alterations induced by viral oncoproteins. Considering that the metabolic switch is recognized as a cancer hallmark, our data also show that novel studies involving the interaction between viral oncoprotein and cell metabolism are mandatory to understand the biochemical mechanism that lead to cell transformation, as well as to develop most efficient therapies to cancer treatment.

\section{Acknowledgments}

The authors thank the Fundação de Amparo à Pesquisa do Estado de São Paulo (FAPESP, process 2014/20617-5) by the financial support. 


\section{References}

1) zur Hausen $H$ (2009) The search for infectious causes of human cancers: where and why. Virology 392: 1-10.

2) Bravo IG, de Sanjosé S, Gottschling M (2010) The clinical importance of understanding the evolution of papillomaviruses. Trends Microbiol 18: 432-8.

3) Ward M, Ward A, Johansson O (2016) Does the mosquito have more of a role in certain cancers than is currently appreciated? - The mosquito cocktail hypothesis. Med Hypotheses 86: 85-91.

4) Mushtaq M, Darekar S, Kashuba E (2016) DNA tumor viruses and cell metabolism. Oxid Med Cell Longev $2016: 1-9$.

5) Araldi R, Módolo D, De-Sá-Júnior P, Consonni S, Carvalho R, Roperto F, et al. (2016) Genetics and metabolic deregulation following cancer initiation: A world to explore. Biomed Pharmacother 82: 449-58.

6) Araldi R, Assaf S, Carvalho R, Carvalho M, Mazzuchelli-de-Souza J, et al. (in press) Papillomaviruses: a systematic review. Genet Mol Biol.

7) Munday J (2014) Bovine and human papillomaviruses: A comparative review. Vet Pathol 1-13.

8) Rapp L, Chen J (1998) The papillomavirus E6 proteins. Biochim Biophys Acta - Rev Cancer1378: 1-19.

9) Adam M, Pini C, Túlio S, Cristina J, Lins L, Torres R, et al.(2015) Assessment of the association between micronuclei and the degree of uterine lesions and viral load in women with human papillomavirus. Cancer Genomics Proteomics 12: 67-72.

10) Stocco dos Santos RC, Lindsey CJ, Ferraz OP, Pinto JR, Mirandola RS, et al.(1998) Bovine papillomavirus transmission and chromosomal aberrations: an experimental model. J Gen Virol 79: 2127-2135.

11) Araldi R, Melo T, Diniz N, Carvalho R, Beçak W, Stocco R (2013) Bovine papillomavirus clastogenic effect analyzed in comet assay. Biomed Res Int 2013: 1-7.

12) Melo T, Araldi R, Pessoa N, De-Sá-Júnior P, Carvalho R, Beçak $\mathrm{W}$, et al. (2015) Bos taurus papillomavirus activity in peripheral blood mononuclear cells: demonstrating a productive infection. Genet Mol Res14: 16712-16727.

13) Araldi R, Melo T, Neves A, Spadacci-Morena D, Magnelli R, Módulo D, et al.(2015) Hyperproliferative action of bovine papillomavirus (BPV): Genetics and histopathological aspects. Genet Mol Res 14: 12942-12954.

14) Potocki L, Lewinska A, Klukowska-Rötzler J, Bielak-zmijewska A, Grabowska W, Rzeszutek I, et al. (2014) Sarcoid-derived fibroblasts: links between genomic instability, energy metabolism and senescence. Biochimie 97: 163-72.

15) Williams V, Filippova M, Filippov V, Payne K, Duerksen-Hughes P (2014) Human papillomavirus type $16 \mathrm{e}^{*}$ induces oxidative stress and DNA damage. J Virol 88: 6751-6761.

16) Wongworawat $Y$, Filippova $M$, Williams V, Filippov V, DuerksenHughes P (2016) Chronic oxidative stress increases the integration frequency of foreign DNA and human papillomavirus 16 in human keratinocytes. Am J Cancer Res 6: 764-780.

17) Doorbar J (2016) Model systems of human papillomavirus-associated disease. J Pathol 238: 166-179.

18) Campos S, Trindade C, Ferraz O, Giovanni D, Lima A, Caetano HA, et al. (2008) Can established cultured papilloma cells harbor bovine papillomavirus? Genet Rolecular Res 7: 1119-1126.

19) Campos S, Melo T, Assaf S, Araldi R, Mazzuchelli-de-Souza J, Sircili M, et al. (2013) Chromosome aberrations in cells infected with bovine papillomavirus: comparing cutaneous papilloma, esophagus papilloma, and urinary bladder lesion cells. ISRN Oncol 2013: 910849.
20) Melo TC, Diniz N, Campos SRC, Ferraz OP, Lindsey CJ, Rieger TT, et al.(2011) Cytogenetic studies in peripheral blood of bovines afflicted by papillomatosis. Vet Comp Oncol 9: 269-274.

21) Diniz N, Melo T, Santos J, Mori E, Brandão P, Richtzenhain L, et al.(2009) Simultaneous presence of bovine papillomavirus in blood and in short-term lymphocyte cultures from dairy cattle in Pernambuco, Brazil. Genet Mol Res8: 1474-1480.

22) Simões R, Barth O (2016) Chromosome aberrations as a biomarker for genomic instability in cell cultures originated from bovines, canines and equines infected with papillomavirus. Int J Appl Sci Biotechnol $4: 104-112$.

23) Warburg $O$ (1953) On the origin of cancer cells. Science 123(3191):309-14.

24) Vander Heiden MG, Cantley LC, Thompson CB (2009) Understanding the Warburg effect: the metabolic requirements of cell proliferation. Science 324: 1029-1033.

25) Ferreira LMR (2010) Cancer metabolism: the Warburg effect today. Exp Mol Pathol 89: 372-80.

26) Hanahan D, Weinberg R (2011) Hallmarks of cancer: the next generation. Cell 144: 646-74.

27) Lu J, Tan M, Cai Q (2015) The Warburg effect in tumor progression: mitochondrial oxidative metabolism as an anti-metastasis mechanism. Cancer Lett 356: 156-164.

28) Cuninghame S, Jackson R, Zehbe I (2014) Hypoxia-inducible factor 1 and its role in viral carcinogenesis. Virology 456-457: 370-383.

29) Reczek C, Chandel N (2015) ROS-dependent signal transduction. Curr Opin Cell Biol 33:8-13.

30) Garber K (2004) Energy boost: the Warburg effect returns in a new theory of cancer. J Natl Cancer Inst 96:1805-1806.

31) Lu H, Forbes R a, Verma A (2002) Hypoxia-inducible factor 1 activation by aerobic glycolysis implicates the Warburg effect in carcinogenesis. J Biol Chem 277: 23111-23115.

32) Dixit D, Sharma V, Ghosh S, Koul N, Mishra PK, Sen E (2009) Manumycin inhibits STAT3, telomerase activity, and growth of glioma cells by elevating intracellular reactive oxygen species generation. Free Radic Biol Med 47: 364-374.

33) Demaria M, Giorgi C, Lebiedzinska M, Esposito G, D’angeli L, Bartoli A, et al. (2010) A STAT3-mediated metabolic switch is involved in tumour transformation and STAT3 addiction. Aging 2: 823-842.

34) Wang B, Hsu SH, Frankel W, Ghoshal K, Jacob ST (2012) Stat3mediated activation of microRNA-23a suppresses gluconeogenesis in hepatocellular carcinoma by down-regulating Glucose-6-phosphatase and peroxisome proliferator-activated receptor gamma, coactivator 1 alpha. Hepatology 56: 186-197.

35) De-Sá-Júnior P, Câmara D, Costa A, Ruiz J, Levy D, et al. (2016) Apoptotic effect of eugenol envolves G2/M phase abrogation accompanied by mitochondrial damage and clastogenic effect on cancer cell in vitro. Phytomedicine 23: 725-735.

36) Araldi R, Giovanni D, Melo T, Diniz N, Mazzuchelli-de-Souza J, et al. (2004) Bovine papillomavirus isolation by ultracentrifugation. J Virol Methods 208: 119-124.

37) Borzacchiello G, Ambrosio V, Roperto S, Poggiali F, Tsirimonakis E, et al. (2003) Bovine papillomavirus type 4 in oesophageal papillomas of cattle from the South of Italy. J Comp Pathol 128: 203-206.

38) Campo M, Coggins L (1982) Molecular cloning of bovine papillomavirus genomes and comparison of their sequence homologies by heteroduplex mapping. J Gen Virol 63: 255-264. 
39) Aghaeepour N, Finak G, Hoos H, Mosmann T, Brinkman R, et al. (2013) Critical assessment of automated flow cytometry data analysis techniques. Nat Methods 10: 228-238.

40) Darzynkiewicz Z, Bedner E, Smolewski P (2001) Flow cytometry in analysis of cell cycle and apoptosis. Semin Hematol 38: 179-193.

41) Jayat C, Ratinaud M (1993) Cell cycle analysis by flow cytometry: principles and applications. Biol Cell 78:15-25.

42) Nunez R (2001) DNA measurement and cell cycle analysis by flow cytometry. Curr Issues Mol Biol 3: 67-70.

43) Mazzuchelli-de-Souza J, Carvalho R, Ruiz R, Melo T, Araldi R, et al.(2013) Expression and in silico analysis of the recombinant bovine papillomavirus E6 protein as a model for viral oncoproteins studies. Biomed Res Int 2013: 421398.

44) Araldi R, Mazzuchelli-de-souza J, Modolo D, Souza E, Melo T, et al. (2015) Mutagenic potential of Bos taurus papillomavirus type 1 E6 recombinant protein : First description. Biomed Res Int 2015:1-15 45) Araldi R, de Melo T, Mendes T, De-Sá-Júnior P, Nozima B, et al. (2015) Using the comet and micronucleus assays for genotoxicity studies: A review. Biomed Pharmacother 72: 74-82.

46) Poli V, Camporeale A (2015) STAT3-Mediated Metabolic Reprograming in Cellular Transformation and Implications for Drug Resistance. Front Oncol 5:1-9.

47) Chan L, Yim E, Choo A (2012) Normalized median fluorescence: An alternative flow cytometry analysis method for tracking human embryonic stem cell states during differentiation. Tissue Engineering: Methods 19:156-165.

48) Herzenberg L, Tung J, Moore W, Herzenberg L, Parks D (2006) Interpreting flow cytometry data: a guide for the perplexed. Nat Immunol 7: 681-685.

49) Araldi R, Carvalho R, Melo T, Diniz N, Sant'Ana T, et al. (2014) Bovine papillomavirus in beef cattle : first description of BPV-12 and putative type BAPV8 in Brazil. Genet Mol Res 13: 5644-5653.

50) Melo T, Carvalho R, Mazzucchelli-de-Souza J, Diniz N, Vasconcelos S, Assaf S, et al. (2014) Phylogenetic classification and clinical aspects of a new putative Deltapapillomavirus associated with skin lesions in cattle. Genet Mol Res13: 2458-2469.

51) Araldi R, Melo T, Neves A, Spadacci-Morena D, Magnelli R, et al. (2015) Hyperproliferative action of bovine papillomavirus (BPV): Genetics and histopathological aspects. Genet Mol Res 14: 1294212954.

52) Carvalho R, Sakata S, Giovanni D, Mori E, Brandão P, et al. (2013) Bovine papillomavirus in Brazil: detection of coinfection of unusual types by a PCR-RFLP method. Biomed Res Int 2013: 270898.

53) Borzacchiello G, Russo V, Gentile F, Roperto F, Venuti A, et al. (2006) Bovine papillomavirus E5 oncoprotein binds to the activated form of the platelet-derived growth factor beta receptor in naturally occurring bovine urinary bladder tumours. Oncogene25: 1251-1260.

54) Wilson AD, Hicks C (2016) Both tumour cells and infiltrating Tcells in equine sarcoids express FOXP3 associated with an immunesupressed cytokine microenvironment. Vet Res 47: 55.

55) Hauk G, Berger J (2016) The role of ATP-dependent machines in regulating genome topology. Curr Opin Struct Biol 36: 85-96.

56) Choi J, Lee K, Zheng Y, Yamaga A, Lai M, et al. (2004) Reactive oxygen species suppress hepatitis $\mathrm{C}$ virus RNA replication in human hepatoma cells. Hepatology 39: 81-9.

57) Gruhne B, Sompallae R, Marescotti D, Kamranvar S, Gastaldello S, et al. (2009) The Epstein-Barr virus nuclear antigen-1 promotes genomic instability via induction of reactive oxygen species. Proc Natl Acad Sci USA 106: 2313-2318.
58) Yen Y, Chen H, Lin Y, Shieh C, Wu-Hsieh B (2008) Enhancement by tumor necrosis factor alpha of dengue virus-induced endothelial cell production of reactive nitrogen and oxygen species is key to hemorrhage development. J Virol 82: 12312-12324.

59) Wake M, Watson C (2015) STAT3 the oncogene - still eluding therapy? FEBS J 282: 2600-2611.

60) Williams V, Brichler S, Khan E, Chami M, Dény P, et al. (2012) Large hepatitis delta antigen activates STAT-3 and NF-kB via oxidative stress. J Viral Hepat 19: 744-753. 
Submit your manuscript to a JScholar journal and benefit from:

ฯ Convenient online submission

ฯ Rigorous peer review

- Immediate publication on acceptance

ฯ Open access: articles freely available online

ब High visibility within the field

- Better discount for your subsequent articles

Submit your manuscript at http://www.jscholaronline.org/submit-manuscript.php 